\title{
Emancipation and Empire: Reconstructing the Worldwide Web of Cotton Production in the Age of the American Civil War
}

\section{Citation}

Beckert, Sven. 2004. Emancipation and empire: Reconstructing in worldwide web of cotton production in the age of the American Civil War. American Historical Review 109(5): 1405-1438.

\section{Published Version}

http://dx.doi.org/10.1086/530931

\section{Permanent link}

http://nrs.harvard.edu/urn-3:HUL.InstRepos:3207344

\section{Terms of Use}

This article was downloaded from Harvard University's DASH repository, and is made available under the terms and conditions applicable to Other Posted Material, as set forth at http:// nrs.harvard.edu/urn-3:HUL.InstRepos:dash.current.terms-of-use\#LAA

\section{Share Your Story}

The Harvard community has made this article openly available. Please share how this access benefits you. Submit a story.

Accessibility 


\title{
Emancipation and Empire: Reconstructing the Worldwide Web of Cotton Production in the Age of the American Civil War
}

\author{
SVEN BECKERT
}

Historians generally viEW the U.S. Civil War as a crucial turning point in the history of the American nation. But it was more than this: the Civil War sparked the explosive transformation of the worldwide web of cotton production and, with it, of global capitalism. The cotton industry was among the world's largest industries at midcentury, drawing on the labor of perhaps 20 million workers. Prior to 1861 , most of the world supply of raw cotton had been produced by slaves on plantations in the American South and was spun into thread and woven into cloth by textile workers in Lancashire. But in the decades following Appomattox, this world had given way to a global empire of cotton structured by multiple and powerful states and their colonies and worked by non-slave labor. Sharecroppers, tenant farmers, and peasants, often highly indebted to local merchants, produced most of the global cotton, a significant fraction of which was grown outside the American South, in such places as India, Egypt, West Africa, Turkmenistan, and Brazil.

The American Civil War was pivotal in these transformations. In its wake, nearly 4 million slaves gained their freedom in the nation that dominated world cotton production, leading to fears among merchants and manufacturers that the disruption of the "deep relationship between slavery and cotton production" might "destroy one of the essential conditions of the mass production" of cotton textiles. ${ }^{1}$ By exploding global confidence in the structure of one of the world's most important industries, the war encouraged a new regime of bureaucrats and industrialists in cotton-consuming countries to secure supplies of the "white gold" not from slaves, but from sharecroppers, tenants, and peasants, decisively shifting the balance between free and coerced labor. And by removing several million bales

I want to thank Sugata Bose, Daniel Botsman, Eric Foner, Charles Forcey, William Gienapp, Michael Grossberg, Steven Hahn, Terry Martin, Lisa McGirr, Martin Shefter, Cyrus Veeser, Richard White, and number of anonymous readers for their critical readings of earlier drafts of this article. Audiences at Stanford University, the University of Leiden, and Jawaharlal Nehru University provided important feedback. I also appreciate the financial support of the Alexander von Humboldt Foundation, and, at Harvard University, of the Davis Center for Russian Studies, the David Rockefeller Center for Latin American Studies, the Asia Center, the Clark/Cooke Fund, and the William F. Milton Fund, which enabled me to do the research on which this article is based. Last but not least, many thanks to Vinod Apte of the Bombay Chamber of Commerce and the American Institute of Indian Studies for their support and to a group of truly superb research assistants, especially Par Cassel, Rui Dong, Chang Liu, Amit Mishra, Daniel Mosteller, Leonid Siderov, Erin Sprangue, Luise Tremel, and Nicole Usher.

${ }^{1}$ Bremer Handelsblatt (October 11, 1862), 335. 
of cotton from global markets between 1861 and 1865, the war forced manufacturers to find new sources for their crucial raw material, catapulting in the decades after Appomattox large areas of the world into the global economy. New forms of labor, the growing encasement of capital and capitalists within imperial nation states, and the rapid spatial expansion of capitalist social relations were the building blocks of a new political economy that dominated global affairs until the "Great War" half a century later. Indeed, the unimaginably long and destructive American struggle, the world's first "raw materials crisis," was midwife to the emergence of new global networks of labor, capital, and state power. ${ }^{2}$ The speed and flexibility with which merchants, manufacturers, and agricultural producers responded to the crisis revealed their adaptability and, not least, their capacity for marshaling new, indirect, but far-reaching forms of state power in place of direct ownership of human beings to secure plentiful labor. One of the most important chapters in the history of global capital and labor, in effect, was written on the battlefields of provincial America.

Even such a quintessential national event as the American Civil War thus had tremendous international implications, which in turn played a decisive role in the terms of its resolution for planters and slaves alike. The war arose in large part out of tensions within the empire of cotton, and in turn transformed the ways in which it linked distant people and places involved in the growing, trading, manufacturing, and consuming of cotton. The core domestic effects of the war-the consolidation of the American nation-state, emancipation, the embrace of a new political economy by Northern mercantile elites, and the spread of capitalist social relations into the Southern countryside-not only moved in tandem but to a significant degree caused parallel developments in Europe, Latin America, Asia, and Africa. ${ }^{3}$ By paralyzing the dominant producer of one of the industrial world's most important commodities, the Civil War brought to a climax the tensions within global capitalism as it had evolved during the first half of the nineteenth century and led to a paradoxical result: the liberation of 4 million slaves in North America and the extension and intensification of imperial control over potential cotton-growing regions in Asia and Africa.

Understandably, historians have viewed the American Civil War primarily as a turning point in the history of the American nation. Its international ramifications, including those on the world's cotton industry, are usually reduced to what foreign

${ }^{2}$ Allen Isaacman and Richard Roberts, "Cotton, Colonialism, and Social History in Sub-Saharan Africa: Introduction," in Cotton, Colonialism, and Social History in Sub-Saharan Africa, Isaacman and Roberts, eds. (Portsmouth, N.H., 1995), 7.

${ }^{3}$ For a general discussion of the global impact of the U.S. Civil War see C. A. Bayly, The Birth of the Modern World, 1780-1914: Global Connections and Comparisons (Malden, Mass., 2004), 161-65. For developments in the United States, see Steven Hahn, The Roots of Southern Populism: Yeoman Farmers and the Transformation of the Georgia Upcountry, 1850-1890 (New York, 1983); Stephen Skowronek, Building A New American State: The Expansion of National Administrative Capacities, 1870-1920 (New York, 1982); Barbara Jeanne Fields, "The Advent of Capitalist Agriculture: The New South in a Bourgeois World," in Essays on the Postbellum Southern Economy, Thavolia Glymph and John J. Kushma, eds. (College Station, Tex., 1985), 73-94; Eric Foner, Reconstruction: America's Unfinished Revolution, 1863-1877 (New York, 1988); Richard Bensel, Yankee Leviathan, The Origins of Central State Authority in America, 1859-1877 (New York, 1990); Sven Beckert, The Monied Metropolis: New York City and the Consolidation of the American Bourgeoisie, 1850-1896 (New York, 2001), chaps. 5,6 , and 10 . 
intervention might have meant to the Union and Confederacy. ${ }^{4}$ Although scholars have largely overlooked the conflict as a turning point in the history of global capitalism, contemporary statesmen, merchants, manufacturers, and intellectuals, especially those residing outside the United States, perceived the war to be as much about cotton's political economy, that is, the particular interaction between states and markets, as about the unity of the American republic. For them, the war posed a set of urgent questions. Who, if not American slaves, would grow cotton and under what systems of labor? What would be the role of states in securing that cotton? And how would the United States fit into the worldwide web of cotton production after the war? Those who acted or commented upon the cotton empire in the nineteenth century-a spectrum as broad as the cotton empire itself, from Richard Cobden, Tsar Alexander II, and Edward Atkinson to Thomas Baring, Louis Napoleon III, and Karl Marx - knew that even the most local manifestations of this cash crop's cultivation and manufacturing were ensnared in a global system and could not be made sense of without it. They understood especially well the tight links between capitalism, cotton, and slavery. For these globally minded politicians, princes, intellectuals, merchants, manufacturers, and journalists, the worldwide web of cotton production was an organic whole that remained incomprehensible when parceled into local, national, or even regional stories. ${ }^{5}$

This essay will revisit these cosmopolitan (and imperial) sensibilities and explore just how the U.S. Civil War recast the worldwide web of cotton production, its prevailing forms of labor and, with them, global capitalism itself. It does not seek to illuminate a chapter of U.S. history from a global perspective but rather to see the role of the United States in a larger transformation of global significance, namely the reconstruction of the worldwide web of cotton growing, trade, and

${ }^{4}$ There is a very substantial literature on this subject, including David M. Potter, "The Civil War in an International Context," in The Legacy of the American Civil War, Harold Woodman, ed. (New York, 1973), 63-72; Henry Blumenthal, "Confederate Diplomacy: Popular Notions and International Realities," Journal of Southern History 32, no. 2 (May 1966): 151-71; Carl N. Degler, One among Many: The Civil War in Comparative Perspective (Gettysburg, Pa., 1990); Harold Melvin Hyman, ed., Heard Round the World: The Impact Abroad of the Civil War, by H. C. Allen et al. (New York, 1969); Frank Lawrence Owsley, King Cotton Diplomacy: Foreign Relations of the Confederate States of America, 2d edn. (Chicago, 1959); Bernarr Cresap, "Frank L. Owsley and King Cotton Diplomacy," Alabama Review 26, no. 4 (1973): 235-51; Charles M. Hubbard, The Burden of Confederate Diplomacy (Knoxville, Tenn., 1998); D. P. Crook, Diplomacy during the American Civil War (New York, 1975); Howard Jones, Union in Peril: The Crisis over British Intervention in the Civil War (Chapel Hill, N.C., 1992).

${ }_{5}$ Edward Baines, History of the Cotton Manufacture in Great Britain; with a notice of its early history in the East... (London, 1835); Thomas Ellison, The Cotton Trade of Great Britain, Including a History of the Liverpool Cotton Market and of the Liverpool Cotton Brokers' Association (London, 1886); Alwin Oppel, Die Baumwolle nach Geschichte, Anbau, Verarbeitung und Handel, sowie nach ihrer Stellung im Volksleben und in der Staatswirtschaft; im Auftrage und mit Unterstützung der Bremer Baumwollbörse (Leipzig, 1902); William B. Dana, Cotton from Seed to Loom: A Hand-Book of Facts for the Daily Use of Producer, Merchant and Consumer (New York, 1878); Morris R. Chew, History of the Kingdom of Cotton and Cotton Statistics of the World (New Orleans, 1884); Gerhart von Schulze-Gaevernitz, The Cotton Trade in England and on the Continent (London, 1895); James A. B. Sherer, Cotton as a World Power: A Study in the Economic Interpretation of History (New York, 1916); Kolonial-Wirtschaftliches Komitee, "Baumwoll-Expedition nach Togo" [1900], pp. 4-6, in R 150F, Fonds Allemand 1 (hereafter FA), 332, Archive du Togo, Lomé, Togo, microfilm copy in Bundesarchiv Berlin (hereafter BA Berlin); Elisée Reclus, "Le Coton et la Crise Américaine," Revue des Deux Mondes 32 (1862): 176-208; Charles J. Sundell to Seward, Stettin, May 15, 1863, Despatches from United States Consuls in Stettin, as quoted in Michael Löffler, Preußens und Sachsens Beziehungen zu den USA während des Sezessionskrieges, 1860-1865 (Münster, 1999), 110. 
manufacturing. I will tell this story in three parts: First, I will sketch the structure of the worldwide cotton industry before the U.S. Civil War, the powerful and immensely profitable status quo against which later changes will be measured. Second, I will examine how the war disrupted some of the fundamental networks of this industry and how people interested in cotton struggled to make sense of this unexpected new world-from the cotton textile workers of Lancashire, Alsace, and Massachusetts, to the merchants of Liverpool, Bombay, and Alexandria, and to the peasants of Egypt's lower Nile, India's Berar, and Brazil's Pernambuco. Here, too, I will explore how the remarkable adaptability of the world's cotton industry may have contributed to the Union's victory in the war. Third, and finally, I will investigate the long-term changes precipitated by the war: the absorption of vast new areas into the world economy, the complex shifts from bonded to non-slave labor, and the rising importance of nation-states in structuring the worldwide web of cotton production. Since the networks of cotton production, trade, and manufacture tied together developments in areas of the world far removed from one another, this essay will make perhaps unexpected links between Antietam and Ashton-under-Lyne, Bull Run and Berar, Tupelo and Togo.

ThE UPHEAvals OF THE AMERICAN Civil WaR were so consequential because by 1861 cotton had become the core ingredient of the world's most important manufacturing industry. In sheer numbers employed, value of output, and profitability, the cotton empire was without parallel. One author, boldly but unscientifically, estimated that as of 1862, fully 20 million people were engaged in the production of cotton and cotton cloth worldwide. ${ }^{6}$ Whole regions such as the mill towns of Massachusetts, Alsace, Saxony, the suburbs of Moscow, and, most important of all, Lancashire, had come to depend on a predictable supply of cheap cotton. In England alone, it was estimated that the livelihood of between one-fifth and one-fourth of all people was based upon the industry, one-tenth of all British capital was invested in it, and close to one-half of all exports consisted of cotton yarn and cloth. ${ }^{7}$

If this industry brought great wealth to European manufacturers and merchants, and bleak employment to hundreds of thousands of mill workers, it also catapulted the United States onto the center stage of the world economy. ${ }^{8}$ After Eli Whitney invented the cotton gin in 1793, American cotton moved in ever-greater quantities to the factories of Europe. Nearly unlimited supplies of labor and recently emptied land, along with an expanding trade infrastructure and established credit networks, enabled the American South to replace early suppliers from Brazil and the West Indies. ${ }^{9}$ By the late $1850 \mathrm{~s}$, the United States accounted for a full 77 percent of the 800 million pounds of cotton consumed in Britain, 90 percent of the 192 million

${ }^{6}$ Reclus, "Le Coton et la Crise Américaine," 176.

7 Dwijendra Tripathi, "A Shot from Afar: India and the Failure of Confederate Diplomacy," Indian Journal of American Studies 10, no. 2 (1980): 75; J. B. Smith (Stockport) in Hansard's Parliamentary Debates, 3d ser., vol. 167 (1862), 754; D. A. Farnie, The English Cotton Industry and the World Market, 1815-1896 (Oxford, 1979), 180. 1961).

${ }^{8}$ Douglass C. North, The Economic Growth of the United States, 1790-1860 (Englewood Cliffs, N.J.,

${ }^{9}$ The Economist (hereafter Econ), February 2, 1861, 117. 
pounds used in France, 60 percent of the 115 million pounds spun in the German Zollverein, and as much as 92 percent of the 102 million pounds manufactured in Russia. ${ }^{10}$ When the British economist J. T. Danson considered in 1857 carefully the "[c]onnection between American Slavery and the British Cotton Manufacture," he concluded that "there is not, and never has been, any considerable source of supply for cotton, excepting the East-Indies, which is not obviously and exclusively maintained by slave-labour."11 The United States and American slavery were thus at the core of the cotton industry and the emerging industrial capitalism.

The world would soon discover just how explosive this growth was. American slavery had begun to threaten the very prosperity it produced, as the distinctive political economy of the cotton South collided ever more powerfully with the incipient political economy of free labor and domestic industrialization that a growing number of northern farmers, workers, and industrialists embraced. ${ }^{12}$ From a global perspective, the outbreak of war between the Confederacy and the Union in April of 1861 was not only a struggle over American territorial integrity and the future of its "peculiar institution" but also about slave labor and nation-building in the world at large, including the particular incorporation of the United States within it. As John Marshman, editor of the Baptist missionary newspaper Friend of India, observed in March of 1863, "it may be said that the prosperity of the South has been based on the gigantic crime of holding three or four millions of human beings in a state of slavery, and it is difficult to divest the mind of the conviction that the day of reckoning from the throne of the Eternal has come." 13

THE OUTBREAK OF THE CIVIL WAR severed in one stroke the global relationships that had underpinned the worldwide web of cotton production and global capitalism for at least two generations. The Confederate government sharpened the crisis by banning all exports to try to force British diplomatic recognition. By the time the Confederacy realized this policy was doomed to fail, a Northern blockade effec-

${ }^{10}$ Econ, January 19, 1861, 58; M. K. Rozhkova, Ekonomicheskie sviazi Rossii so Srednei Aziei: 40-60-e gody XIX veka (Moscow, 1963), table 17, 61; "Vliianie Amerikanskoi Voiny na Khlopchatobumazhnoe delo v Rossii" [The effect of the American war on the cotton business in Russia], Moskva 25 (1867), January 25, 1867; M. Gately, The Development of the Russian Cotton Textile Industry in the Pre-Revolutionary Years, 1861-1913 (PhD dissertation, University of Kansas, 1968), Kaiserliches Statistisches Amt, Statistisches Jahrbuch für das Deutsche Reich, Erster Jahrgang, 1880 (Berlin, 1880), 87; U.S. Department of the Treasury, Bureau of Statistics, Cotton in Commerce, Statistics of United States, United Kingdom, France, Germany, Egypt, and British India (Washington, D.C., 1895), 29. The French numbers are for 1859; see Claude Fohlen, L'Industrie Textile au Temps du Second Empire (Paris, 1956), 284, 514. On the importance of the United States to world cotton markets see Gavin Wright, "Cotton Competition and the Post-Bellum Recovery of the American South," Journal of Economic History 34, no. 3 (September 1974): 610-35; Wright, Old South, New South: Revolutions in the Southern Economy since the Civil War (New York, 1986).

11 J. T. Danson, "On the Existing Connection between American Slavery and the British Cotton Manufacture," in Journal of the Statistical Society of London 20 (March 1857), 7. For a similar argument see also Reclus, "Le Coton et la Crise Américaine," 176, 187. Arguments about the connection between capitalism and slavery can also be found in Philip McMichael, "Slavery in Capitalism: The Rise and Demise of the U.S. Ante-Bellum Cotton Culture," in Theory and Society 20 (June 1991): 321-49, Joseph Inikori, Africans and the Industrial Revolution in England: A Study in International Trade and Economic Development (New York, 2003); and Eric Williams, Capitalism and Slavery (Chapel Hill, N.C., 1994).

12 See for this argument Beckert, Monied Metropolis, chaps. 3 and 4.

13 John Marshman quoted in Times of India (hereafter, ToI), "Overland Summary," March 12, 1863. 
tively kept most cotton from leaving the South. Consequently, exports to Europe fell from 3.8 million bales in 1860 to virtually nothing in 1862, despite the best efforts of Southern smugglers. The effects of the resulting "cotton famine," as it came to be known, quickly rippled outward, reshaping industry and society in places ranging from Manchester to Mulhouse, from Berar to Pernambuco, and from Bremen to Alexandria. With only slight hyperbole, the Chamber of Commerce in the Saxon city of Chemnitz could report that "never in the history of trade have there been such grand and consequential movements as in the past four years." As early as the summer of 1862 , some of the defining trade relationships of the world economy had collapsed. ${ }^{14}$

After using up the unusually large stocks of cotton, yarn, and cloth that had accumulated in ports and mills, a mad scramble to fill the vacuum left by the embargo on Southern cotton ensued. This was the more frantic as nobody could predict when the war would end, and when, if ever, cotton production would revive in the American South. By early 1862, cotton imports from the United States fell by 96 percent, and mills began shutting down for a few days each week, or entirely. Tens of thousands of operatives soon found themselves out of work. By early 1863 , a quarter of the inhabitants of Lancashire, more than 500,000 individuals, received some form of public assistance. Workers, demanding relief, rioted in the streets of several British cotton towns, underscoring the explosive social consequences of the cotton famine. Similar crisis erupted on the European continent, as posters went up in the textile towns of Alsace proclaiming "Du pain ou la mort" (bread or death). ${ }^{15}$

The suffering of cotton operatives and the losses sustained by manufacturers compelled government bureaucrats to find new ways to secure cotton. Cotton, after all, was central to their national economies, as well as to the maintenance of social peace. Some officials advocated recognition of the Confederacy and breaking the Union blockade. Others hoped for new sources of cotton from places outside the United States. When, in the spring of 1862, Napoleon III conversed with William L. Dayton, the U.S. Minister in Paris, on various aspects of the cotton problem, the emperor concluded the interview by saying: "I hope . . that something will be done by your government to relieve the difficulties here, growing out of the want of cotton." On numerous occasions, the House of Commons, the House of Lords, and the French Senate debated the cotton question. This intense concern with securing access to cheaply priced raw materials essential to national industries was a clear departure from the past. Since the 1780 s, raw cotton markets had been decisively dominated by merchants: now, in an awkward return to mercantilist policies, cotton

${ }_{14}$ The quote is from Jahresbericht der Handels- und Gewerbekammer Chemnitz (1865): 6, as quoted in Löffler, Preußens und Sachsens Beziehungen, 302; see also Matthew B. Hammond, The Cotton Industry: An Essay in American Economic History (New York, 1897), appendix.

15 Ellison, The Cotton Trade of Great Britain, table 1, appendix; Liverpool Mercury (hereafter, LM), February 22, 1864; March 25, 1863. On the relief efforts in Lancashire, see John Watts, The Facts of the Cotton Famine (London, 1866); Hyman, Heard Round the World, 132. Lynn Case, ed., French Opinion on the United States and Mexico 1860-1867: Extracts from the Reports of the Procureurs Généraux (New York, 1936), 123-25; on Germany see Löffler, Preußens und Sachsens Beziehungen, 126, 147. "Du pain ou la mort" is quoted in Thomas A. Sancton, "The Myth of French Worker Support for the North in the American Civil War," French Historical Studies 11, no. 1 (1979): 66. 
had become a matter of state. The cotton famine, in fact, became the school in which a new kind of imperialism began to emerge. ${ }^{16}$ (See Figure 1.)

Meanwhile, 4,600 miles to the east of Liverpool and 9,200 miles away from Antietam, Indian merchants and cultivators, British colonial bureaucrats, and Manchester manufacturers embarked on a frantic race to grow cotton for world markets. ${ }^{17}$ India, indeed, had captured the imagination of British textile entrepreneurs as early as the $1820 \mathrm{~s}$. Accustomed to variations in harvests and weather, such entrepreneurs were aware of the potential danger of dependence on one supplier for cotton. But very little had come from these promotional efforts. Lackluster support by the colonial state, America's overwhelming market dominance, India's feudal social structure, and lack of transportation infrastructure retarded cotton production for export. Indeed, as The Economist noted before the outbreak of the Civil War, "[a]s long as there were negroes in the Southern States, and those negroes could be kept to work, it would have been venturesome, not enterprising" to grow cotton for world markets elsewhere-including in India. ${ }^{18}$

The bombardment of Fort Sumter, however, announced that India's hour had come. With feverish energy, British cotton capitalists and colonial bureaucrats worked to increase India's cotton output and move it to market. Manchester manufacturers shipped cottonseed to Bombay to be distributed to growers; they moved cotton gins and cotton presses into the countryside; and they talked about investing in railroads to remove cotton to the coast. They also pressed a newly perceptive British government for massive infrastructure investments, changes in criminal codes to make the adulteration of cotton a crime, and new property laws to make for clearly defined and easily marketable property in land. Perhaps most important was their pressure to change Indian contract law in order to facilitate

${ }^{16} \mathrm{LM}$, August 12, 1862: 7; for the British government's concern about the social impact of the cotton famine see, for example, the documents in $\mathrm{HO} 45,7523$, Home Office, Public Record Office (hereafter, PRO), Kew, London, United Kingdom. Even before the outbreak of the war, British Foreign Secretary Lord John Russell had hastened to assure cotton manufacturers in Manchester that his government would do all in its power to secure cotton from sources outside the United States. The letter is quoted in $L M$, January 22, 1861, 2. For the William L. Dayton quotation see Dayton to William Henry Seward, Paris, March 25, 1862, Despatches, France, State Department Correspondence, National Archives, Washington, D.C. (hereafter, NA). Napoleon argued that social unrest would follow if cotton could not be secured. Thurlow Weed to Seward, Paris, April 4, 1862, Despatches, France, State Department Correspondence, NA. On diplomatic pressure see also William S. Thayer to Seward, London, July 11, 1862, Private letter, U.S. Consulate, Alexandria, Despatches from U.S. Consuls in Alexandria, NA; Löffler, Preußens und Sachsens Beziehungen, 111.

17 Manchester Chamber of Commerce, The Forty-First Annual Report of the Board of Directors for the Year 1861 (Manchester, 1862), 21. For evidence of this pressure see also Manchester Chamber of Commerce, The Forty-Third Annual Report of the Board of Directors for the Year 1863 (Manchester, 1866), 6; Proceedings of the Manchester Chamber of Commerce, 1858-1867, M8/2/6, Archives of the Manchester Chamber of Commerce, Manchester Archives and Local Studies, Manchester, UK.

${ }^{18}$ For earlier efforts to increase cotton production in India, see Anti-Cant, India v. America: A Letter to the Chairman of the Hon. East India Company, On Cotton (London, 1850); John Briggs, The Cotton Trade of India with a Map of India, Coloured to Indicate the Different Spots Whereon all the Varieties of Cotton which are Brought into the British Market have been Successfully Cultivated (London, 1840); John Chapman, The Cotton and Commerce of India: Considered in Relation to the Interests of Great Britain; with Remarks on Railway Communication in the Bombay Presidency (London, 1851); The Cotton Trade of India (London, 1839); Thomas Williamson, Two Letters on the Advantages of Railway Communication in Western India, Addressed to the Right Hon. Lord Wharncliffe, Chairman of the Great Indian Peninsula Railway Company (England); The Cotton Trade of India, Part II: Its Future Prospects (London [1840]); Walter R. Cassels, Cotton: An Account of its Culture in the Bombay Presidency (Bombay, 1862), $16-237$. For the quotation see Econ, February 2, 1861, 117. 


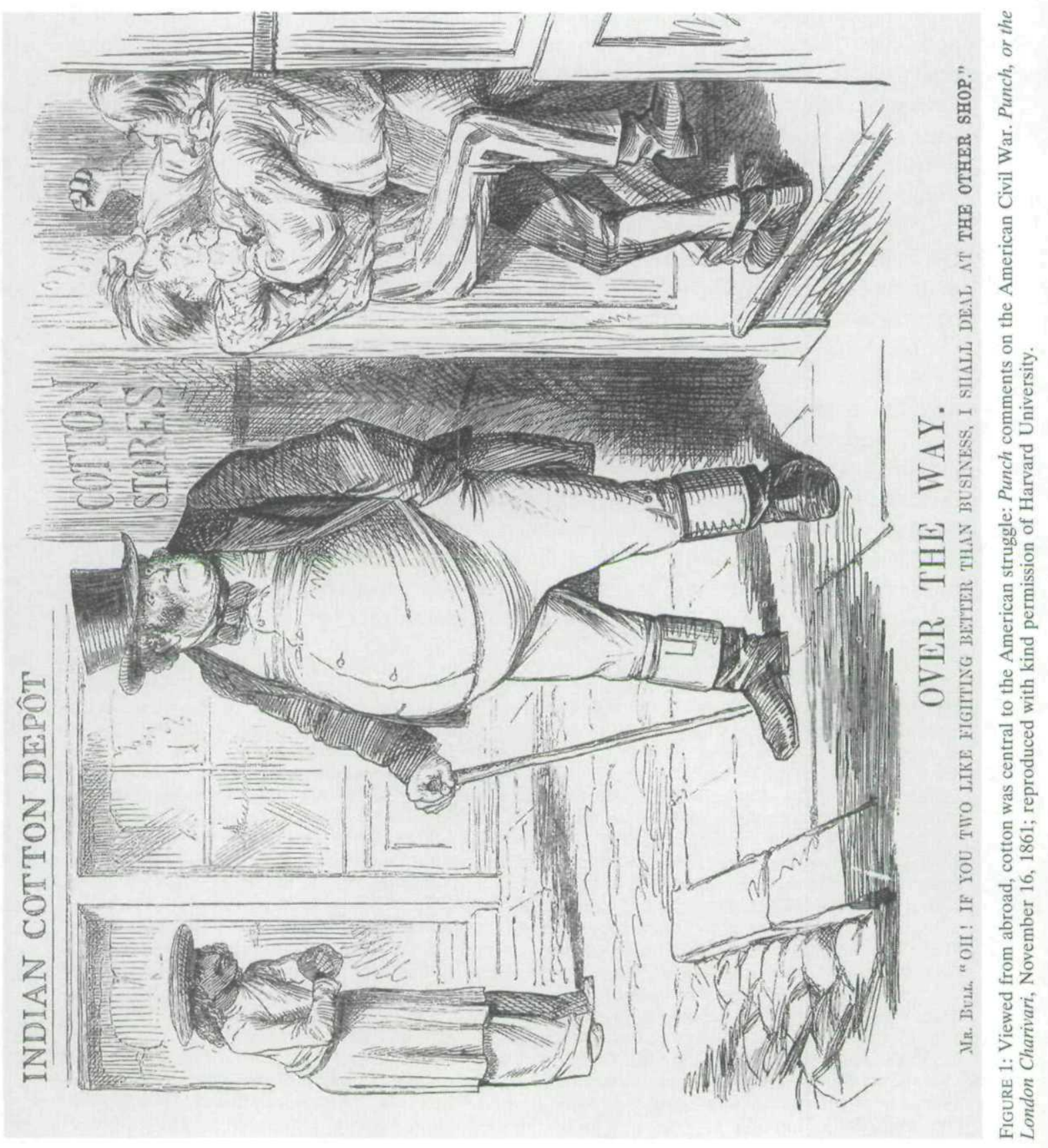


European investment in cotton production. Cotton capitalists wanted to make "penal the breach of contract where advances have been made," giving "the advancer an absolute lien upon the crop he advances upon to the extent of his advances." If merchants could secure such an absolute claim on cotton grown with the support of their capital, investment would be encouraged. Such a system would permit cultivators to devote their efforts entirely to cash crops, since advances would allow them to purchase food grains before their own cotton crop ripened. ${ }^{19}$

The effectiveness of these new measures was furthered by rapidly rising prices, which eased the transition from subsistence to world market production. The value of Indian cotton jumped fourfold during the first two years of the war. ${ }^{20}$ As a result, Indian cultivators began planting cotton on new land as well as on land once devoted to food crops. This unprecedented dedication to export agriculture paid off handsomely for them during the war years and decisively helped European cotton manufacturers secure some of the raw material they needed to keep their factories running: whereas India had only contributed 16 percent of Britain's supply of raw cotton in 1860, and 1.1 percent of France's in 1857, it contributed 75 percent in 1862 in Britain and as much as 70 percent in France. Some of this cotton had been diverted from domestic use and competing foreign markets (especially China), while the rest was the result of a 50 percent increase in production. Rural producers in western India in general and Berar in particular were most responsible for this increase in output. The explosive growth of Bombay can indeed be traced to the Civil War years, as Indian cotton left its old channels of trade into Bengal and moved toward the great European entrepôt. European merchants and manufacturers complained about the poor quality of Indian cotton-it was less clean, of shorter

${ }^{19}$ For the efforts by manufacturers, see Charles Wood to William Reeves, March 18, 1861, Letterbook, March 18 to May 25, LB 7, F 78, MSS EUR, Wood Papers, Oriental and India Office Collection, British Library, London, UK (hereafter, IOL); Wood to Earl of Elgin, October 25, 1862, Letterbook, July 3 to December 31, 1862, LB 11, F 78, MSS EUR, Wood Papers, IOL; Letter from Messrs. Mosley and Hurst, Agents to the Cotton Supply Association, to W. Greq, Esq, Secretary to the Government of India, dated June 20, 1861, reprinted in ToI, July 18, 1861, 3. For the quotation see Wood to W. J. Grant, May 9, 1861, in LB 7, F 78, MSS EUR, Wood Papers, IOL. On the debates on the passage of a law that made the adulteration of cotton a crime, see the ToI reporting in 1863, for example on February 12, 1863, "Overland Summary," 6-7; also "Overland Summary," ToI, March 27, 1863, 1. For pressures to change Indian contract law, see Manchester Chamber of Commerce, The Forty-First Annual Report, 13. See also Manchester Chamber of Commerce, The Forty-Second Annual Report of the Board of Directors for the Year 1862 (Manchester, 1863), 37; Wood to William Maine, October 9, 1862, Letterbook, July 3 to December 31, 1862, LB 11, F 78, MSS EUR, Wood Papers, IOL; reprint of a resolution of the home department, February 28, 1861, Supplement to the Calcutta Gazette, March 2, 1861, in Papers relating to Cotton Cultivation in India, 106, Wood Papers, MSS EUR F 78, IOL. Some of the mechanisms are related well in John Henry Rivett-Carnac, Many Memories of Life in India, at Home, and Abroad (Edinburgh, 1910), 165-93. For the debate during the war between manufacturers and government officials, see also Wood to Elgin, October 25, 1862, LB 11, F 78, MSS EUR, Wood Papers, IOL; Wood to William Maine, October 9, 1862, Letterbook, July 3 to December 31, 1862, LB 11, F 78, MSS EUR, Wood Papers, IOL; Hansard Parliamentary Debates, 3d ser., vol. 167 (1862), 767; Manchester Chamber of Commerce, Forty-Second Annual Report, 1863, 26; Manchester Chamber of Commerce, Forty-First Annual Report; LM, September 24, 1862, 6; Wood to Sir George Clerk, March 18, 1861, in LB 7, March 18 to May 25, 1861, F 78, MSS EUR, IOL; Peter Harnetty, "The Imperialism of Free Trade: Lancashire, India, and the Cotton Supply Question, 1861-1865,"Journal of British Studies 6, no. 1 (November 1966): 75-76. For the debate as a whole, see Dwijendra Tripathi, "Opportunism of Free Trade: Lancashire Cotton Famine and Indian Cotton Cultivation," Indian Economic and Social History Review 4, no. 3 (1967): 255-63.

${ }^{20}$ Neil Charlesworth, Peasants and Imperial Rule: Agriculture and Agrarian Society in the Bombay Presidency, 1850-1935 (Cambridge, 1985), 135. 
staple, and required the adjustment of machines-but Indian cotton prevented the total collapse of the European cotton industries. ${ }^{21}$

The swirl of activity that transformed parts of India during the Civil War years also rippled through Egypt's lower Nile delta. There, the Ottoman's Viceroy Sa id Pasha turned his personal attention to converting his own large landholdings into vast cotton farms. According to Massachusetts cotton manufacturer Edward Atkinson, Sa id Pasha became at a stroke "the largest and best cultivator of cotton in the world." From the viceroy's vantage point, his long-term project of modernizing Egypt through the sale of cotton on world markets, a project begun about four decades earlier under Muhammad 'Ali, now seemed closer than ever to fruition. New railroads, new canals, new cotton gins, and new cotton presses were built in the countryside. By 1864, 40 percent of all fertile land in lower Egypt had been converted to cotton cultivation. Egyptian cotton exports increased five times during the Civil War years, marking a permanent economic change of such significance that historians of Egypt rank the American Civil War among the most crucial events in its nineteenth-century history. ${ }^{22}$

The outward radiating effects of the Civil War also reached the northeastern coast of Brazil. Decades earlier, cultivators there had occupied land belonging to large estate owners in and around Pernambuco, where they survived primarily as subsistence farmers. Over time, however, these peasants began to cultivate small amounts of cotton to obtain cash for necessities and taxes. When prices for cotton surged during the war and British merchants provided sufficient advances to enable farmers to devote all their energies to cotton, they abandoned their subsistence crops to plant cotton for the world market. Collectively, these cultivators more than doubled Brazilian cotton exports between 1860 and $1865 .{ }^{23}$ (See Table 1).

Rural cultivators in other regions of the world also responded to the cotton famine in the industrial states. Argentinean, Chinese, and Central Asian cotton now increasingly found its way into world markets. Even African merchants along the

${ }^{21}$ Reichsenquete für die Baumwollen- und Leinen-Industrie, Statistische Ermittelungen, Heft (Berlin, 1878) 1, 56-58; James A. Mann , The Cotton Trade of Great Britain: Its Rise, Progress, and Present Extent (London, 1860), 103, 112, 132; “Overland Summary,” February 12, 1862, Tol, 1; October 3, 1862, ToI, 2; Harnetty, "The Imperialism of Free Trade," 92; Statistical Abstracts for the United Kingdom in Each of the Last Fifteen Years from 1857 to 1871 (London, 1872), 48-49; Fohlen, L'Industrie Textile, 287, 514; Bombay Chamber of Commerce, Report of the Bombay Chamber of Commerce for the Year 1863-64 (Bombay, 1865), 1; Frenise A. Logan, "India-Britain's Substitute for American Cotton, 1861-1865," Journal of Southern History 24, no. 4 (1958): 476. See also Manchester Chamber of Commerce, The Forty-Fourth Annual Report of the Board of Directors for the Year 1864 (Manchester, 1865), 18; B. R. Mitchell, European Historical Statistics, 1750-1970 (New York, 1976), E14; Frenise A. Logan, "India's Loss of the British Cotton Market after 1865," Journal of Southern History 31, no. 1 (1965): 40-50. On the issue of cotton versus grain, see "Overland Summary," ToI, January 14, 1864, 3; Walter Richard Cassels, Cotton: An Account of its Culture in the Bombay Presidency, Prepared from Government Records and other Authentic Sources, in Accordance with a Resolution of the Government of India (Bombay, 1862), 205. For a discussion of Egyptian peasants replacing their food crops with cotton, see Earle, "Egyptian Cotton and the American Civil War," 521.

${ }^{22}$ Quoted in Edward Atkinson, "The Future Supply of Cotton," North American Review (April 1864), 481; Edward Mead Earle, "Egyptian Cotton and the American Civil War," Political Science Quarterly 41, no. 4 (1926): 520-45; E. R. J. Owen, Cotton and the Egyptian Economy (Oxford, 1969 ), 89.

${ }^{23}$ Estatísticas Históricas do Brasil: Séries Econômicas Demográficas e Socias de 1550 a 1988 (Rio de Janeiro, 1990), 346. They were urged on by the Manchester Chamber of Commerce and Lord Russell himself. See Manchester Chamber of Commerce, The Forty-First Annual Report, 8; Stanley J. Stein, The Brazilian Cotton Manufacture: Textile Development in an Underdeveloped Area, 1850-1950 (Cambridge, Mass., 1957), 43. 


\begin{tabular}{|l|l|l|l|l|l|l|l|}
\hline & $\mathbf{1 8 6 0}$ & $\mathbf{1 8 6 1}$ & $\mathbf{1 8 6 2}$ & $\mathbf{1 8 6 3}$ & $\mathbf{1 8 6 4}$ & $\mathbf{1 8 6 5}$ & $\mathbf{1 8 6 6}$ \\
\hline India & 346 & 381 & 395 & 473 & 550 & 525 & 803 \\
Egypt & 50.1 & 59.6 & 82 & 128.7 & 174 & 250.7 & 178.5 \\
Brazil & 27.4 & 21.6 & 30.8 & 38.3 & 47.6 & 60.7 & 102.3 \\
\hline
\end{tabular}

TABLE 1: Cotton Exports from India, Egypt, and Brazil, 1860-1866, in Million Pounds. Sources: Government of India, Annual Statement of the Trade and Navigation of British India and Foreign Countries vol. 5 (Calcutta, 1872); vol. 9 (Calcutta, 1876); Roger Owen, Cotton and the Egyptian Economy, 1820-1914 (Oxford, 1969), 90; Estatísticas historica do Brasil (Rio de Janeiro, 1990), 346.

coast of what would eventually become the German colony of Togo employed their slaves in the production of cotton for shipment to Liverpool. Such desperate search for cotton bred fanciful scenarios among political economists, manufacturers, and merchants who hoped that this or that region of the world would fill the gap left by the war. L'Afrique est le vrai pays du coton (Africa is the true land of cotton) pronounced one French observer optimistically in 1864. To the chagrin of cotton manufacturers and gullible investors, not all of these plans worked out during the war years, and the quantity of African, Argentinean, or Turkestan cotton sold on the world market remained insignificant. ${ }^{24}$

Yet during the American Civil War, merchants, manufacturers, workers, cultivators, and statesmen had sown the seeds for a recasting of the empire of cotton. Because of their efforts, Indian, Egyptian, and Brazilian cotton had become a major presence on western markets. Their experience during the cotton famine, moreover, had opened bold new vistas on colonial adventure and state involvement in commodity markets. While private investment and mild lobbying of colonial policies had characterized the antebellum efforts of cotton manufacturers, the cotton famine sharply raised the sophistication and dependence of these cotton capitalists on the state. Nationalism and colonialism suddenly had become matters of urgent self-interest. Last but not least, cotton interests had invented in those years a new system of mobilizing non-slave labor, characterized by cultivators enmeshed in debt, share croppers burdened by crop liens, and rural producers with little political power. Infusing European capital into peasant production allowed cotton growing to expand beyond the wildest imagination of its protagonists, even though one of its traditional pillars-slavery—was about to be destroyed.

24 Alejandro E. Bunge, Las Industrias del Norte: Construcción al Estudio de una Nueva Politica Económica Argentina (Buenos Aires, 1922), 209-10; LM, November 9, 1863, 6; LM, January 3, 1865, 6; Manchester Chamber of Commerce, The Forty-Fourth Annual Report (1865), 16; Donna J. E. Maier, "Persistence of Precolonial Patterns of Production: Cotton in German Togoland, 1800-1914," in Allen Isaacman and Richard Roberts, eds., Cotton, Colonialism and Social History in Sub-Saharan Africa (Portsmouth, 1995), 75. See also Peter Sebald, Togo 1884-1914; Eine Geschichte der deutschen "Musterkolonie" auf der Grundlage amtlicher Quellen (Berlin, 1988), 30; O. F. Metzger, Unsere alte Kolonie Togo (Neudamm, 1941), 242; "Der Baumwollbau in Togo, seine bisherige Entwicklung, und sein jetztiger Stand," draft of an unsigned article to be published in Kolonialwirtschaftliche Mitteilungen (ca. 1902), 8224, R 1001, BA Berlin; Céleste Duval, Question Cotonnière: La France peut s'emparer du Monopole du Coton par l'Afrique, elle peut rendre l'Angleterre, l'Europe, ses Tributaires; L'Afrique est le Vrai Pays du Coton (Paris, 1864), 7. 
The American Civil War spurred rapid changes in regions far removed from North America. These changes, in turn, had an impact on the war itself. Perhaps most importantly, they tended to influence the sentiments of the world's cotton merchants, manufacturers, and workers as well as their governments towards the American conflict. Especially for merchants, but also for some manufacturers and even a few workers, the desire to secure cotton at first made them powerful advocates for the cause of the Confederacy. Yet their ability to reshape the world cotton industry by giving India, Egypt, and other places important new roles moved them increasingly into the Union camp, persuading them that emancipation and cotton production might not be mutually exclusive.

Although most rulers, capitalists, and workers in Britain, France, Prussia, and Russia, including those involved with cotton, made no secret of their pro-Union proclivities, a powerful minority regularly used the cotton famine to justify their demands for British or French intervention. Tellingly, Liverpool, the world's largest cotton port, was the most pro-Confederate place in the world outside the Confederacy itself. Liverpool merchants helped bring out cotton from ports blockaded by the Union navy, built ships of war for the Confederacy, and supplied the South with military equipment and credit. And Liverpool was not alone. The Manchester Southern Club and the Manchester Southern Independence Association also agitated for the South. In 1862, thousands of participants, many of them workers, staged rallies in British cotton towns, demanding government recognition of the Confederacy. In France, as early as October 1861, delegations of cotton merchants and manufacturers converged on Paris to press the government to help make U.S. cotton accessible again and chambers of commerce in various cotton growing cities pleaded with Napoleon to recognize the Confederacy and to bring the blockade to an end. ${ }^{25}$ These sentiments mattered because they could potentially influence the position of various powers, especially of Britain and France, to the American war. The Union had an overwhelming interest in maintaining the

${ }^{25}$ Blumenthal, "Confederate Diplomacy," 151-71; Degler, One among Many; Hyman, Heard Round the World; Owsley, King Cotton Diplomacy; Cresap, "Frank L. Owsley and King Cotton Diplomacy"; Hubbard, The Burden of Confederate Diplomacy; Crook, Diplomacy during the American Civil War; Jones, Union in Peril; Lynn Marshall Case, The United States and France: Civil War Diplomacy (Philadelphia, 1970); Jones, Union in Peril; Löffler, Preußens und Sachsens Beziehungen. For proConfederate sentiments see, for example, $L M$, June 24, 1861, 3; August 12, 1861, 2; September 20, 1861, 6; October 8, 1861, 5; October 15, 1861, 5; December 18, 1861, 6; April 18, 1862, 6. For pressure to recognize the Confederate government, see $L M$, July 16, 1862, 5; November 19, 1862, 3. For a controversial debate on slavery, see the letters to the editor to the $L M$ printed on February 7 and February 9, 1863, both on page 3; LM, May 21, 1863, 7. See also John D. Pelzer, "Liverpool and the American Civil War," History Today 40, no. 3 (March 1990): 46; The Porcupine, November 9, 1861, 61. For material support for the Confederacy see, for example, copy of letter from Thomas Haines Dudley, U.S. Consulate Liverpool, to Charles Francis Adams, Liverpool, May 4, 1864, in Seward Papers, Library of Congress (hereafter LC), Washington, D.C.; Thomas Haines Dudley to William H. Seward, Liverpool, September 3, 1864, in Seward Papers, LC; LM, May 3, 1864, 6. Fraser, Trenholm \& Company, operating out of Liverpool, secured funds for the Confederacy, built ships of war, and participated in blockade running. See the Fraser, Trenholm \& Company Papers, Merseyside Maritime Museum, Liverpool, UK (hereafter, MMML). Liverpool merchants went into business with agents of the Confederacy in trading cotton through the federal blockade. Letter by W. Fernie, Liverpool, to Fraser, Trenholm \& Co, B/FT 1/13, Fraser, Trenholm \& Company Papers, MMML. Also see $L M$, February 4, 1863, 3; Pelzer, "Liverpool and the American War," 46. For Manchester, see LM, May 23, 1863, 6; October 6, 1863, 6; October 17, 1863, 3; February 1, 1864, 7; for working-class support see $L M$, May 2, 1862, 7; August 9, 1862, 5. For France, see Case and Spencer, The United States and France, 179. See also Manchester Chamber of Commerce, Forty-First Annual Report, 21-22. 
neutrality of European governments, while the Confederacy saw gaining recognition as its single most important foreign policy goal. Of course there were good reasons not to intervene-Britain had to consider the fate of its Canadian provinces, and its growing dependence on wheat and corn imports from the United States, while continental powers such as France, Russia, and Prussia had an interest in maintaining a strong United States to balance British economic and military power. But recognition always remained a possibility, and those who advocated it usually argued for the advantages of an independent Confederacy as a source of raw cotton and a low tariff market for European goods. ${ }^{26}$

Because the Union government recognized that the Achilles heel of its diplomacy was the shortage of cotton, it tried to undermine pro-Confederate sentiment by actively encouraging cotton production in other parts of the world, especially in Egypt. There was no little irony in the fact that the government of the world's greatest producer of cotton would encourage competitors to its most important export crop to emerge, but the military and political pressure was so overwhelming that it justified even extraordinary steps. Washington, wrote William H. Seward in April 1862, had "an obvious duty to examine the capacities of other countries for cotton culture and stimulate it as much as possible, and thus to counteract the destructive designs of the factious monopolists at home."27

These calculations of American policy makers, as expected, did help to defuse tensions between Washington and European capitals. In the spring of 1862, Baring Brothers Liverpool expressed their view that war between the United States and

${ }^{26}$ For the Confederacy, see W. L. Trenholm to Charles Kuhn Prioleau (Liverpool), New York, June 21, 1865, B/FT 1/137, Fraser, Trenholm \& Company Papers, MMML. On the importance of wheat imports to Britain, see, for example, Thayer to Seward, London, July 19, 1862, Seward Papers, LDC. For a far-flung debate on why not to recognize the Confederacy see Hansard's Parliamentary Debates, 3d ser., vol. 171 (1863), 1771-1842. For British dependence on wheat and corn imports see especially 1795. See also Duke of Argyll to John Russell, October 11, 1862, Box 25, PRO 30/22, Lord John Russell Papers, PRO. On the Prussian desire for a strong United States to counterbalance British influence, see Löfler, Preußens und Sachsens, 59. For various arguments made in the House of Commons for recognizing the Confederacy, see Hansard's Parliamentary Debates vol. 171, June 30, 1863, 1771-1842. See also Hansard Parliamentary Debates, 3d ser., vol. 165 (1862), 1165. See also Martin T. Tupper to Abraham Lincoln, May 13, 1861 (Support from England), in Abraham Lincoln, Abraham Lincoln Papers, ser. 1, General Correspondence (n.p., 1833-1916), Library of Congress. The diplomatic correspondence between the British Foreign Office and the British embassy in Washington D.C. suggests that Foreign Minister Earl Russell along with the French government exerted considerable pressure on the U.S. government by reminding it again and again of Europe's need for cotton. See Lord John Russell Papers, PRO. See also Lord Lyons to Earl Russell, Washington, July 28, 1863, in United States, Washington Legislation, Private Correspondence, Box 37, 30/22, Lord John Russell Papers, PRO; Wood to Earl of Elgin, August 9, 1862, LB 11, Letterbook, July 3 to December 31, 1862, F 78, MSS EUR, Wood Papers, IOL. American diplomats, too, were frequently reminded of Europe's urgent need for cotton. Sanford to Seward, April 10, 1862, Seward Papers, Manuscripts Division, LC, as quoted in Case and Spencer, The United States and France, 290. See also Thayer to Seward, London, July 19, 1862, Seward Papers, LC; Dayton to Adams, Paris, November 21, 1862, AM 15236, Correspondence, Letters Sent A-C, Box I, Dayton Papers, quoted in Case, The United States and France, 371.

${ }^{27}$ Seward quoted in Thayer to Seward, March 5, 1863, U.S. Consulate, Alexandria, Despatches from U.S. Consuls in Alexandria, NA. See also David R. Serpell, "American Consular Activities in Egypt, 1849-1863," Journal of Modern History 10, no. 3 (1938): 344-63; Thayer to Seward, Despatch number 23, Alexandria, November 5, 1862, in Despatches of the U.S. Consul in Alexandria to Seward, NA; Seward to Thayer, Washington, December 15, 1862, Seward Papers, LC; Trabulsi to Seward, Alexandria, August 12, 1862 and Thayer to Seward, April 1, 1862, in Despatches of the U.S. Consul in Alexandria to Seward, NA. For the dispatches to Seward on cotton see, for example, Thayer to Seward, Alexandria, July 20, 1861, in Despatches from U.S. Consuls in Alexandria, 1835-1873, NA. 
Great Britain was less likely "provided we get a large import from India." 28 Edward Atkinson, Boston cotton manufacturer himself, was similarly relieved that the "supposed dependence of Europe upon the Cotton States has proved to be an utter fallacy." 29 Indeed, once significant amounts of cotton arrived from sources other than the United States, the political pressure on European governments from cotton interests declined. ${ }^{30}$ By 1863 , even those whose livelihood depended on cotton and who had once been advocates of the cause of the Southern states began to envision the possibility of a non-slave empire of cotton, seeing the Southern struggle for independence as a dangerous disruption to the world economy. ${ }^{31}$ After all, cotton merchants and manufactures, unlike Southern planters and their government, were not invested in a particular source of cotton, such as the American South, nor in a particular system of labor to produce it, such as slavery. All they required was a secure and predictable supply of inexpensive cotton. To the degree that this conversion of cotton traders had to do with the arrival of cotton from non-slave areas, Egyptian, South American, and Indian cultivators and merchants played a small role in contributing to Northern victory in the Civil War. ${ }^{32}$

RESPONDING TO THE IMMEDIATE economic, social, and political effects of the cotton famine represented the most formidable challenge to merchants, manufacturers, rural producers, workers, and statesmen in the Americas, Europe, Asia, and Africa. Yet the true significance of the war to the worldwide web of cotton growing, trade, and manufacturing rested on the war's destruction of the most fundamental pillars on which the empire of cotton, and with it industrial capitalism, had been built for six decades: slavery, a powerful planter class in the American South, an industry structured on the relationship between Lancashire and the United States, and networks of trade dominated by merchants operating in relatively open markets. This particular combination of land, labor, capital, and state power had enabled the production of rapidly growing quantities of cotton at falling prices and thus had made possible industrial revolution. Yet in 1865, it was beyond repair. ${ }^{33}$

Cotton merchants and manufacturers did not let go of this earlier world easily. For too long, American slavery had guaranteed their prosperity. Profits derived from the

\footnotetext{
${ }^{28}$ Baring Brothers Liverpool to Joshua Bates, Liverpool, February 12, 1862, in HC 35: 1862, House Correspondence, Baring Brothers, ING Baring Archives, London, UK.

${ }^{29}$ Atkinson, "The Future Supply of Cotton," 478. Atkinson is here not identified as the author, but his authorship becomes clear from his correspondence with Charles E. Norton. See N 297, Letters, 1861-1864, Edward A. Atkinson Papers, Massachusetts Historical Society, Boston, Mass. See also John Bright to Atkinson, London, May 29, 1862, Box N 298, Edward A. Atkinson Papers, Massachusetts Historical Society, Boston, Mass.

${ }^{30}$ This is the impression from reading the Annual Reports of the Manchester Chamber of Commerce. For a sense of relief by cotton interests, see, for example, Manchester Chamber of Commerce, Forty-Third Annual Report, 17, 25; LM, August 8, 1864, 7; August 9, 1864, August 7, 10, 1864, 3; August 31, 1864, 7; September 22, 1864, 7; October 31, 1864, 7.

31 LM, January 4, 1864, 8.

32 This general argument is also made by Tripathi, "A Shot From Afar."

${ }^{33}$ Bremer Handelsblatt (April 22, 1865), 142. The institution of slavery itself, of course, thrived for a few more decades in places such as Cuba, Brazil, and Africa. By and large, however, cotton was no longer produced by slaves. See Suzanne Miers and Richard Roberts, eds. The End of Slavery in Africa (Madison, Wisc., 1988).
} 
trade in slave-grown cotton had fueled the wealth of Liverpool, Le Havre, Bremen, and New York, and indeed quite a few merchants had gotten their start in the slave trade itself. ${ }^{34}$ Even for those who sincerely believed slavery to be an evil, the abstract appeal of liberty diminished once actual emancipation became a real possibility. The Economist was a case in point. Generally a strong opponent of slavery, its editors nonetheless feared that if abolition came to the American South, "[t]he catastrophe would be so terrible, its accompaniments so shocking, and its results everywhere and in every way so deplorable, that we most earnestly pray it may be averted." 35

This was hardly a principled defense of slavery. Yet the reaction of merchants and manufacturers reflected their understanding of the sources of their own prosperity. After all, at prevailing antebellum world market prices, few cultivators in India, Brazil, Africa, or, for that matter, the American South, had produced very much cotton for European markets-despite the best efforts of some manufacturers. The experience of emancipation in the Caribbean a few decades earlier, moreover, had taught cotton capitalists to be concerned about cash-crop production by former slaves. Cotton production in Saint Domingue had collapsed upon emancipation and in British Guyana, once an important cotton growing region, freedpeople had moved into subsistence farming, "with evil consequences." 36

Despite these misgivings, slavery could not be resurrected. Although the British Minister to Washington expressed hope in 1865 that "measures are being taken to force the Negroes to work," freedpeople in the United States, supported by powerful interests in the North, successfully insisted on making the war a war of their liberation. ${ }^{37}$ Moreover, the upheavals of the war suggested that the United States might have lost its capacity to produce sufficient cotton to feed the growing global demand. In 1865, it had become clear that a novel combination of land, labor, capital, and state power had to be found to secure the fabulous amounts of inexpensive cotton needed by cotton manufacturers the world over.

Capitalists and imperial bureaucrats worked zealously on such a reconstruction of the worldwide web of cotton production. In articles and books, speeches and letters, they belabored the question if and where cotton could be grown by non-slave labor. Massachusetts cotton manufacturer Edward Atkinson, for example, contributed to this debate in 1861 with his Cheap Cotton by Free Labor, British colonial official W. H. Holmes followed suit a year later with Free Cotton: How and Where to Grow it, and an anonymous French author added his voice the same year with Les Blancs et les Noirs en Amérique et le Coton dans les deux Mondes. ${ }^{38}$

Soon such treatises were informed by lessons drawn from the Civil War experiences themselves. The sudden turn to non-slave cotton during the Civil War years in Egypt, Brazil, and India as well as in Union-controlled zones of the

${ }^{34}$ Such as John Tarleton, who, during the 1780 s, dealt in cotton only as a sideline to his main activity, trading in human beings. See Tarleton Papers, 920 TAR, Liverpool Records Office, Liverpool, UK. See also $L M$, September 22, 1863, 7 .

${ }^{35}$ Econ, January 19, 1861, 58

${ }^{36}$ W. H. Holmes, Free Cotton: How and Where to Grow it (London, 1862), 18.

${ }^{37}$ W. A. Bruce to Earl Russell, Washington, May 22, 1865, 22/28, 30, Lord John Russell Papers, PRO.

${ }^{38}$ Holmes, Free Cotton; Edward Atkinson, Cheap Cotton by Free Labor: By A Cotton Manufacturer (Boston, 1861); Les Blancs et les Noirs en Amérique et le Coton dans les deux Mondes, Par L'auteur de La Paix en Europe par l'Alliance Anglo-Francaise (Paris, 1862). 
American South represented, after all, a gigantic experiment of how a world of cotton without slaves could be shaped. These rehearsals for reconstruction suggested two somewhat contradictory conclusions. ${ }^{39}$ First, cotton experts reckoned that enough cotton could be procured to permit cotton manufacturing to continue its dramatic expansion even without slavery. This was, for example, the judgment of the English Ladies' Free Grown Cotton movement, a loose association of women who committed themselves to purchasing only cloth produced with free labor cotton. ${ }^{40}$ And, perhaps most optimistically, it was embraced by Republicans in the United States such as Edward Atkinson, who believed that cotton production in the American South could be expanded dramatically through the use of "free labor"that is, as long as freedpeople would not engage in subsistence agriculture. ${ }^{41}$

Yet the Civil War experience also had shown that non-slave cotton had entered world markets only under conditions of unsustainable high prices; after all, the price of Indian cotton had quadrupled and earlier efforts to bring Indian cotton to market at lower prices had largely failed. Moreover, from the perspective of 1864 and 1865, emancipation was leading to dangerous social turmoil in the American South. It was thus reasonable to expect that freedom would bring a permanent reduction in the supplies of raw cotton-an expectation expressed most directly by the fact that postbellum cotton prices (for American middling in Liverpool) remained for ten years well above their prewar level. ${ }^{42}$

Despite this uncertainty, the wartime rehearsals for reconstruction provided cotton capitalists and government bureaucrats with important insights into how the growing of cotton for world markets might be resurrected. Most importantly, they learned that labor, not land, constrained the production of cotton. ${ }^{43}$ Members of the Manchester Cotton Supply Association, the world's leading experts on such matters, argued already during the war that three things were necessary for successful cotton cultivation: "soil and climate fit for the growth of cotton"-and labor. They understood that land and climate of a "quality equal, and in many cases superior, to that" of America was available in many different parts of the globe. But these experts on global cotton found that "only two regions" possessed "the very first requisite, which was labor"- West Africa and India. ${ }^{44}$

But how should this labor be mobilized? During the American Civil War and its

39 The theme of "rehearsal for reconstruction" is taken from Willie Lee Nichols Rose, Rehearsal for Reconstruction: The Port Royal Experiment (Indianapolis, 1964).

${ }^{40} L M$, September $23,1863,6$. This was also the conclusion of an increasing number of people in Liverpool, who by 1863 wrote an ever-increasing number of letters to the editor of the $L M$ to make their antislavery voices heard. See, for example, $L M$, January $19,1863,6 ; L M$, January 24, $1863,7$.

${ }^{41}$ Atkinson, Cheap Cotton by Free Labor, Atkinson Papers, Massachusetts Historical Society, Boston, Mass. See also Manchester Chamber of Commerce, The Forty-First Annual Report, 33.

${ }^{42}$ Already in 1862 , Mr. Caird argued in the House of Commons, that "[t]he advantages which the Southern States had hitherto derived from slave cultivation would to a great extent be at an end." Hansard Parliamentary Debates, 3d ser., vol. 167 (1862), 791. See also LM, January 3, 1865, 6; LM, April 25, 1865, 6; LM, May 13, 1865, 6. For prices, see Todd, World's Cotton Crops, 429-32.

${ }_{43}$ August Etienne, Die Baumwollzucht im Wirtschaftsprogram der deutschen Übersee-Politk (Berlin, 1902), 28. The theme of labor shortage was also an important subject in discussions on the expansion of Indian cotton production during the U.S. Civil War. See, for example, ToI, October 18, 1861, 3; February 27, 1863, 6; Zeitfragen, May 1, 1911, 1.

${ }^{44}$ In the "West of Africa, though there was labor, the people were savage." LM, June 12, 1861, 3. As the superintendent of the Cotton Gin Factory in the Dharwar Collectorate reported in May of 1862, "Although the cultivation of native cotton is capable of extension to an enormous degree, yet the 
immediate aftermath, the efforts of cotton interests focused squarely on accessing labor in regions that formerly had not grown significant amounts of cotton for European markets. This strategy had a long history; since the 1820 s, for example, largely unsuccessful efforts had been afoot to enable the production of greater amounts of cotton for British markets in India. The Civil War, however, focused the energies of capitalists and statesmen in unprecedented ways, and, indeed, their efforts resulted in a sustained increase in cotton production in India, Brazil, Egypt, and Central Asia. Aided by dramatic advances in transportation and communications technology, their activities rapidly expanded capitalist social relations through a sharp surge of global economic integration, resulting in a long-lasting commercialization of regions that before 1861 had remained remote from world markets. As the Revue de Deux Mondes observed perceptively, "[t]he emancipation of the enslaved races and the regeneration of the people of the East" were intimately connected. ${ }^{45}$ This geographic spread of world market cotton production was the first new pillar of the postwar empire of cotton.

The expansion of cotton production for world markets was most momentous in India. As the Bombay Chamber of Commerce observed at the end of the war, the "emancipation of American slaves [was] a matter of paramount importance" for the future of India's cotton industry, signifying a permanent change in the agricultural structure and trade of India. While it is true, as many historians have observed, that Indian rural producers were not able to hold on to their dominant position on world cotton markets after the war, their production for export still rose rapidly, expanding from 260 million pounds in 1858 to nearly 1.2 billion pounds in 1914 , despite the simultaneous explosion in the number of domestic spinning mills. (See Figure 2.) Export merchants, however, no longer sold most of this much larger crop to manufacturers in India's two traditional markets-Great Britain and China-but instead found buyers in continental Europe, and, after the turn of the century, among Japanese spinners. In the thirty years after 1860, continental European consumption of Indian cotton increased sixty-two-fold. ${ }^{46}$ (See Table 2).

\footnotetext{
amount of labour available is barely sufficient to clean the quantity now produced." Quoted in ToI, February 12, 1863, 3.

45 Reclus, "Le Coton et la Crise Américaine," 208.

${ }^{46}$ Bombay Chamber of Commerce, Report of the Bombay Chamber of Commerce for the Year 1865-66 (Bombay, 1867), 213. The permanence of this change is also emphasized by Maurus Staubli, Reich und Arm mit Baumwolle: Exportorientierte Landwirtschaft und soziale Stratifikation am Beispiel des Baumwollanbaus im indischen Distrikt Khandesh (Dekkan), 1850-1914 (Stuttgart, 1994), 66; Mann, Cotton Trade, 132; Statistical Abstracts for British India from 1911-1912 to 1920-1921 (London, 1924), 476-77. There is an unfortunate tendency in much of the literature on the effects of the Civil War on India to limit one's view to the relationship between India and Britain, which entirely misses the more important trade in raw cotton between India and continental Europe as well as Japan. For the "empire centric" view, see, for example, Logan, "India's Loss of the British Cotton Market after 1865" and also Wright, "Cotton Competition and the Post-Bellum Recovery of the American South." On the importance of continental European markets, see also Harry Rivett-Carnac, "Report on the Cotton Department for the Year 1868-69" (Bombay, 1869), 139; C. B. Pritchard, "Annual Report on Cotton for the Bombay Presidency for the Year 1882-83" (Bombay, 1883), 2. On the importance of the Japanese market, see S. V. Fitzgerald and A. E. Nelson, Central Provinces District Gazetteers, Amraoti District, vol. A (Bombay, 1911), 192. On increased imports of Indian cotton in Europe, see Dwijendra Tripathi, "India's Challenge to America in European Markets, 1876-1900," Indian Journal of American Studies 1, no. 1 (1969): 57-65; Statistical Abstracts for the United Kingdom for Each of the Fifteen Years from 1910 to 1924 (London, 1926), 114-15; Todd, World's Cotton Crops, 45. For the reasons why Indian
} 


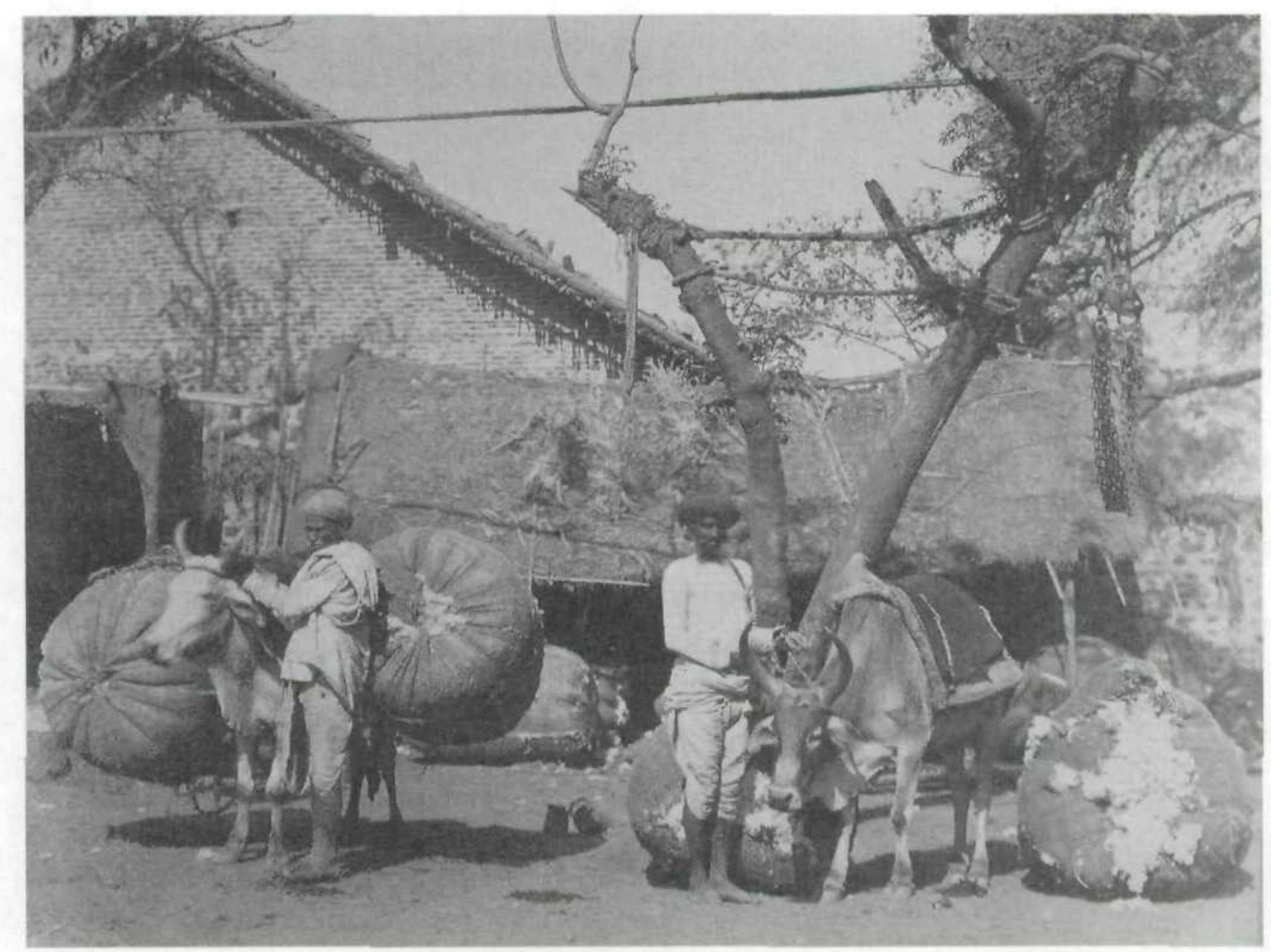

Figure 2: Securing new sources of cotton: Indian and European merchants trade at the Bombay cotton market, ca. 1870. Reproduced with kind permission of Volkart Stiftung, Winterthur, Switzerland.

Elements of the Indian story played out in Brazil and Egypt as well. In Brazil, cotton exports had averaged 32.4 million pounds per year during the 1850 s, rising to more than 61 million pounds in 1865. During the following thirty years (1866-1896), Brazil exported an average of 66.7 million pounds of cotton annually, compared with an average of 26.9 million pounds in the three decades before the Civil War (1831-1860)-despite the simultaneous growth of domestic cotton manufacturing by a factor of 53. Meanwhile in Egypt, fellaheen quintupled their cotton production between 1860 and 1865 from 50.1 million to 250.7 million pounds. After the war, their production at first fell quite significantly to about 125 million pounds, but by 1872 merchants shipped more than 200 million pounds from the port of Alexandria to European destinations. Even during the post-Civil War trough of cotton production, Egypt's output was still two-and-a-half times as large as it had been before the Civil War. Indian, Brazilian, and Egyptian cotton in particular thus had become a significant new presence on world cotton markets. By 1883 , cotton from there had captured a full 31 percent of the continental European market or a little more than twice as much as in 1860.47

cotton found a ready market on the continent, see "Report by F. M. W. Schofield, Department of Revenue and Agriculture, Simla, 15 September 1888," in Department of Revenue and Agriculture, Fibres and Silk Branch, April 1889, nos. 6-8, Part B, National Archives of India, New Delhi, India (hereafter, NAI).

${ }_{47}$ The Brazil discussion is based on Estatísticas Históricas do Brasil, 346. On the number of spindles, 


\begin{tabular}{|l|l|}
\hline Decade & $\begin{array}{l}\text { Million } \\
\text { lbs }\end{array}$ \\
\hline $\mathbf{1 8 5 0 s}$ & 226.5 \\
\hline $\mathbf{1 8 6 0 s}$ & 384.4 \\
$\mathbf{1 8 7 0 s}$ & 554.8 \\
$\mathbf{1 8 8 0 s}$ & 469.5 \\
$\mathbf{1 8 9 0 s}$ & 536.9 \\
$\mathbf{1 9 0 0 s}$ & 710.6 \\
\hline $\mathbf{1 9 1 0 s}$ & 920.1 \\
\hline
\end{tabular}

TABLE 2: Cotton Exports from India: Average Annual Exports, by Decade, in Million Pounds. Sources: Government of India, Annual Statement of the Trade and Navigation of British India with Foreign Countries, vol. 5 (Calcutta, 1872); Government of India, Annual Statement of the Trade and Navigation of British India with Foreign Countries, vol. 9 (Calcutta, 1876); Statistical Abstracts Relating to British India from $1874 / 5$ to $1883 / 4$ (London, 1885), 11; John Todd, World's Cotton Crops (London, 1915), 45; Statistical Abstracts for British India from 1911-12 to 1920-21 (London, 1924), 476-77.

The rapid geographic expansion of the worldwide web of cotton production was deeply entangled with efforts to find new ways to motivate rural cultivators to grow the white gold and move it to market. Until 1861, American slavery had answered the question as to how to extract labor for cotton production, but during the war it had become obvious that slaves would never again produce much cotton for world markets, even in regions in which slavery persisted, such as in Brazil and Africa. ${ }^{48}$ A new system of labor thus had to be invented. Antebellum experiences suggested that this would be difficult, since non-slave cotton had arrived only in small quantities in the ports of Liverpool, Bremen, and LeHavre. Rural cultivators in control of both their labor and land usually had resisted growing cotton for world markets at prices competitive with slave-grown cotton. Cotton merchants did not succeed in extracting sufficient amounts of cotton from precapitalist producers at what they considered to be reasonable prices-neither in India nor in Africa, Egypt, or, for that matter, the upcountry of the Southern United States. Moreover, efforts by cotton planters to rely on wage workers failed, as people the world over refused to work for wages on cotton plantations. ${ }^{49}$

see Stein, The Brazilian Cotton Manufacture, 191. One observer argues that without the war, the rapid expansion of cotton production in Egypt would have taken half a century. See Earle, "Egyptian Cotton and the American Civil War," 522. For the conversion of cantars into pounds, see Owen, Cotton and the Egyptian Economy, 382-83. I assumed here that one cantar equaled $100 \mathrm{lbs}$. See also Owen, Cotton and the Egyptian Economy, 90,123,124, 197; the permanence of this change is also emphasized by Alan Richards, Egypt's Agricultural Development, 1800-1980: Technical and Social Change (Boulder, Colo., 1982), 31; Ellison, The Cotton Trade of Great Britain, 91.

${ }_{48}$ Luiz Cordelio Barbosa, "Cotton in Nineteenth Century Brazil: Dependency and Development," (PhD dissertation, University of Washington, 1989), 170.

${ }^{49}$ Kolonial-Wirtschaftliches Komitee, Deutsch-koloniale Baumwoll-Unternehmungen, Bericht XI (Spring 1909), p. 28, in 8224, R 1001, BA Berlin; Thaddeus Sunseri, "Die Baumwollfrage: Cotton Colonialism in German East Africa," Central European History 34, no. 1 (2001), 46, 48. Peasant resistance against colonial cotton projects in a very different context is also described in Allen Isaacman et al., "Cotton is the Mother of Poverty": Peasant Resistance to Forced Cotton Production in Mozambique, 1938-1961," The International Journal of African Historical Studies 13, no. 4 (1980), 581-615; Kolonial-Wirtschaftliches Komitee, "Verhandlungen der Baumwoll-Kommission des Kolonial-Wirtschaftlichen Komitees vom 25. April 1912,” 169; Eric Foner, Reconstruction. 
Out of these failures an entirely different system of labor control was born: unlike in sugar production, which, after emancipation, relied to an important extent on indentured laborers, cotton would be grown by cultivators who would work their own or rented land with the input of family labor and metropolitan capital. Sharecropping, crop liens, and powerful local merchants in control of capital characterized the countryside in which they lived. ${ }^{50}$ These cotton farmers, the world over, were deeply enmeshed in debt, vulnerable to world market fluctuations, generally poor, subject to newly created vagrancy statutes and labor contracts designed to keep them on the land, and politically marginalized. They were often subject to extra-economic coercion. These were the people who would grow ever-larger amounts of cotton in the new empire of cotton, from India to Central Asia, from Egypt to the United States. ${ }^{51}$

The global story of how this new system of labor was forged can be told from many different vantage points, as its fundamental dynamics were strikingly similar on all continents. Here, however, a closer look at one region within India, Berar, should suffice. Only acquired by the British in 1853, colonial administrators and British cotton interests quickly saw Berar as a promising region for the growth of cotton. After 1861, the effects of the distant American Civil War turned it virtually upside down. In the following four years, cotton acreage nearly doubled, and then doubled once more by the 1880 s. The war, reported one observer, has "positively electrified Berar. Before this, cotton had been one out of many staples. It now became the prevailing, absorbing, predominating product." While some of this increase resulted from planting formerly fallow lands, the percentage of land devoted to cotton instead of food grains rose as well-from 21 percent in 1861 to 30 percent in 1865 , and to 38 percent by 1900 . By 1867 , as one observer put it, Berar had "become a perfect garden of cotton"- a garden that eventually produced more of the fiber than all of Egypt. ${ }^{52}$

The annihilation of both space and time was at the core of Berar's transforma-

50 See Herbert S. Klein and Stanley L. Engerman, "The Transition from Slave to Free Labor: Notes on a Comparative Economic Model," in Between Slavery and Free Labor: The Spanish-Speaking Caribbean in the Nineteenth Century, Manuel Moreno Fraginals, Frank Moya Pons, and Engerman, eds. (Baltimore, Md., 1985), 255-70.

51 This was a different system of labor than the one that emerged in the global sugar industry after emancipation. There, indentured workers took on a prominent role. The difference is probably related to the fact that sugar production is much more capital intensive than the growing of cotton, and, moreover, because there are efficiencies of scale in sugar which do not exist in cotton. For the effects of emancipation on sugar, see especially Rebecca J. Scott, Slave Emancipation in Cuba: The Transition to Free Labor, 1860-1899 (Princeton, 1985); David Northrup, Indentured Labor in the Age of Imperialism, 1834-1922 (New York, 1995); Frederick Cooper, Thomas C. Holt, and Rebecca Scott, Beyond Slavery: Explorations of Race, Labor, and Citizenship in Postemancipation Societies (Chapel Hill, N.C., 2000).

52 For the quote see Alfred Comyn Lyall, ed., Gazetteer for the Haidarabad Assigned Districts, Commonly Called Berar, 1870 (Bombay, 1870), 137. All the numbers are from Satya, Cotton and Famine in Berar, 184. A very good introduction to the ways in which the British acquired Berar is reprinted in Moulvie Syed Mahdi Ali, ed, Hyderabad Affairs, 5 vols. (Bombay, 1883). See also Lord Dalhousie to Charles Wood, June 3, 1843, F78, 17, MSS EUR, Wood Papers, IOL; "Lord Dalhousie's Minute on his Indian Administration-Hyderabad," Madras, Spectator, August 2, 1856, in Hyderabad Affairs, 2 (1883), as quoted in Laxman D. Satya, Cotton and Famine in Berar (New Delhi, 1997), 58; Nelson, Central Provinces District Gazetteers: Amraoti District, 248; Harry Rivett-Carnac, "Report on the Cotton Department for the Year 1867-1868," (Bombay, 1868), 10. Maurus Staubli, studying the impact of the transition to a cotton export industry in another region of India, the district of Khandesh, came to very similar conclusions. See Staubli, Reich und Arm mit Baumwolle. 
tion. Before the 1850 s, cotton sent to Bombay was transported on bullocks in journeys taking many weeks. During the Civil War years, however, railroads began dissecting Berar, enabling merchants to ship cotton rapidly and cheaply. By 1870 , thanks to government investments, the railroad finally reached the Berar town of Khangaon, "the largest cotton outpost of the British empire," where merchants from Britain, Germany, France, Italy, Switzerland, and the Habsburg Empire congregated to acquire raw cotton, gin and press it, and then ship it to Europe. Market integration advanced rapidly and once telegraphic communication with England had become possible in 1868 and the Suez Canal opened in 1869, a Liverpool merchant could wire an order for cotton to Berar and receive it on the shores of the Mersey just six weeks later. ${ }^{53}$

While railroads and telegraphs created the infrastructure to sell Berar cotton on world markets, it took the intervention of the British colonial state to recast Berar's social structure and natural environment in ways that encouraged cultivators to produce cotton. When British colonial administrators created private property in land, they facilitated the infusion of European capital, a goal furthered by legal changes penalizing the adulteration of cotton and altering contract law. ${ }^{54}$ It was in such a revolutionized social environment that rural producers responded to the rapid rise of cotton prices after 1861 by growing an ever-greater quantity of the cash crop. In the process, they took on debts to buy implements, purchase seed, acquire the means of subsistence during the cotton-growing season, and pay taxes, often at exorbitant rates of interest (a minimum of 12 percent per year, but 24 or even 60 percent were common), and in turn they signed over their cotton crop to moneylenders, usually many months before the harvest. ${ }^{55}$

As elsewhere in the empire of cotton, the money advanced to cultivators by indigenous moneylenders increasingly came from European merchants, such as the Volkarts, the Rallis, and the Barings who advanced capital to local merchants and agents who in turn would provide it to moneylenders who would grant credit to cotton cultivators. Since these local moneylenders obtained unlimited title to the property and labor of their debtors, it gave them the "power to utterly ruin and enslave the debtor." During the nineteenth century, they used this power to control peasant labor, and not their land, which was of little value without people to work it. Their authority rested upon the impartial rule of law, courts, and ultimately the

${ }^{53}$ F. R. S. Briggs, The Cotton Trade of India: Its Past and Present Condition (London, 1839), 83; Satya, Cotton and Famine in Berar, 142. India and-Bengal Despatches, vol. 82, August 17, 1853, 1140-1142 from Board of Directors, EIC London, to Financial/Railway Department, Government of India, quoted in Satya, Cotton and Famine in Berar, 142. On the telegraph, see Rivett-Carnac, "Report on the Cotton Department for the Year 1867-68," 100. On the occasion of the opening of the railroad no other than the British viceroy himself linked the new state of affairs explicitly to the American Civil War. "Opening of the Khangaon Railway," ToI, March 11, 1870, reprinted in Ali, Hyderabad Affairs, vol. 4, 199. On Khangaon see also Rivett-Carnac, "Report on the Cotton Department for the Year 1868-69," 98ff; Lyall, ed., Gazetteer for the Haidarabad Assigned Districts, Commonly Called Berar, 1870 , 230; Rivett-Carnac, "Report on the Cotton Department for the Year 1867-68," 100; Journal of the Society of Arts 24 (February 25, 1876), 260.

54 Nelson, Central Provinces District Gazetteers, Amraoti District, 228. This was also the case in Egypt. See Owen, Cotton and the Egyptian Economy, 113. British capital also financed advances to Brazilian cotton planters. See Barbosa, "Cotton in Nineteenth Century Brazil: Dependency and Development," 99.

55 Nelson, Central Provinces District Gazetteers, Amraoti District, 253. In Egypt, rates from 12 to 60 percent annually were also typical. Owen, Cotton and the Egyptian Economy, 107. 
state, and thus was entirely unlike the claims to power inherent in the relationship between masters and their slaves. ${ }^{56}$

As a result of these swift changes, a region that as late as 1853 had remained largely removed from world markets and had a subsistence and village-orientated economy with a substantial household manufacturing sector reoriented its economic activities around cotton. This had significant implications for Berar's social structure. Cotton expansion pushed more people into agricultural labor. Many banjaras (traditional owners of carts who had transported cotton) now labored in Berar's fields. Spinners and weavers, their markets challenged by British imports, found themselves unable to compete for the crucial raw material, and also moved into the agricultural proletariat, their numbers decreasing by as much as 50 percent during the war. Thus in a large swath of India, integration into the world market went hand in hand with the movement of people from manufacturing into agriculture. Indeed, high cotton prices during the war years both stimulated the planting of cotton and undermined its transformation into yarn and cloth by Indian spinners and weavers, making in effect a two-prong assault on the equilibrium of the subcontinent's traditional economy. A wave of rapid "peasantization" and proletarianization descended upon Berar, and, by 1891,30 to 40 percent of its inhabitants had become landless agricultural laborers. Such a transformation was exactly what British colonial interests had in mind when they had pushed into Berar in the first place. As the British Cotton Commissioner Harry Rivett-Carnac remarked in 1869 , "Now it is not too much to hope, that, with a branch railway to this tract, European piece goods might be imported so as to undersell the native cloth. And the effect would be, that, not only would a larger supply of the raw material be obtained - for what is now worked up into yarn would be exported-but the larger population now employed in spinning and weaving would be made available for agricultural labour, and thus the jungle land might be broken up and the cultivation extended." 57

Stories such as this can be told for places all over the empire of cotton. Throughout Maharashtra, for example, British efforts to increase the revenue and encourage peasants to engage in distant markets led to the undermining of the collective nature of villages, making individual peasants (instead of villages as a whole) responsible for taxes, and handing judicial power to distant courts instead of village-based and peasant-dominated tribunals. One of the effects of these changes was that moneylenders gained new power over peasants' land and labor, especially in the wake of the "dislocations in the economy of Maharashtra caused by the Civil

56 For the quote see "Report of the Committee on the Riots in Poona and Ahednagar, 1875" (Bombay, 1876), 80. See also Nelson, Central Provinces District Gazetteers, Amraoti District, 253; Lestock Reid, Administration Report of the Cotton Department for the Year 1876-77 (Bombay, 1877), 41; Printed letter from Chief Secretary to the Government of Bombay to A. O. Hume, Secretary to the Government of India, Department of Revenue, Agriculture, and Commerce, March 1877 and Savashiva Ballal Goundey, Honorary Secretary, Sarvajanik Sabha, to the Chief Secretary of Government in Bombay, Puna, April 14, 1877, both in compilation No. 765, Report of the Deccan Riots Commission, Compilation Volume 161, 1877, Revenue Department, Maharashtra State Archive, Mumbai, India.

57 Rivett-Carnac, "Report on the Cotton Department for the Year 1868-69," 91. The American South, after the Civil War, also became much more dependent on cotton and an importer of foodstuffs. See Wright, Old South, New South, 35; Gavin Wright and Howard Kunreuther, "Cotton, Corn and Risk in the Nineteenth Century,” Journal of Economic History 35, no. 3 (1975): 526-51. 
War in America," when peasants, in order to pay their taxes and plant their crops, became ever more dependent on advances. In Khandesh, the greater orientation toward cotton agriculture and the attendant legal and social changes resulted in ever-increasing percentage of land devoted to the "white gold" (19 percent in $1861 / 62,44$ percent in 1901/02) and a wave of proletarianization, so that by 1872 already one in four adult men owned no land and worked for wages. In Egypt as well, the booming cotton export industry, according to historian Alan Richards, "destroyed the quasi-communal forms of land tenure, broke up the protective web of village social relations, replaced them with private property in land and individual tax responsibility and helped create four classes: large landowners ... rich peasants ... small peasant landowners, and a landless class.” In 1907, Richards estimates that 37 percent of all agriculturalists had become landless laborers. Meanwhile, the American South witnessed a transformation of agriculture and class relations just as radical. The ever-deeper involvement of sharecroppers and Southern upcountry farmers in the world market, along with harsh credit arrangements, led to a vast expansion of cotton production. Just like in India and Egypt, merchants linked to metropolitan capitalists, not planters or rural cultivators, emerged as the newly dominating social group in the countryside. Aided by vagrancy laws, labor codes, crop lien laws, and annual labor contracts, they enforced the new rules of the market. White tenant farmers, not former slaves, accounted for much of the increase in cotton production, as they were drawn away from subsistence agriculture and into production for world markets. ${ }^{58}$

Everywhere, the emergence of new systems of labor resulted in a rapid, vast, and permanent increase in the production of cotton for world markets. Most significantly, American farmers recovered, despite all predictions to the contrary, their position as the world's leading producers of raw cotton. By 1870 , their total output surpassed that of 1860 for the first time, by 1877 , they regained their prewar market share in Great Britain, the world's most important cotton market, and by 1880 , they exported more cotton than they had in 1860.59 Indeed, by 1891 , sharecroppers, family farmers, and plantation owners in the United States grew twice as much cotton as in 1861 and supplied 81 percent of the British, 66 percent of the French, and 61 percent of the German market. ${ }^{60}$ Altogether, by 1900, growers the world

58 Ravinder Kumar, Western India in the Nineteenth Century: A Study in the Social History of Maharashtra (London, 1968), 35, 59, 151, 161; Staubli, Reich und Arm mit Baumwolle, 58, 68, 114-15, 187; Alan Richards, Egypt's Agricultural Development: 1800-1980: Technical and Social Change (Boulder, Colo., 1982), 55, 61. In Turkestan, many years later, the result would be quite similar. John Whitman, "Turkestan Cotton in Imperial Russia," American Slavic and East European Review 15, no. 2 (1956): 190-205. On economic change in the postbellum South, see also Foner, Reconstruction, 392-411; Gavin Wright, The Political Economy of the Cotton South: Households, Markets, and Wealth in the Nineteenth Century (New York, 1978), 166-76; Wright, Old South, New South, 34, 107; Hahn, The Roots of Southern Populism.

59 U.S. Department of Commerce, Bureau of the Census, Historical Statistics of the United States, Colonial Times to the Present (New York, 1976), 518, 899; U.S. Department of the Treasury, Bureau of Statistics Cotton in Commerce: Statistics of United States, United Kingdom, France, Germany, Egypt, and British India (Washington, D.C., 1895), 29.

${ }^{60}$ Historical Statistics of the United States, 518; Tableau Décennal du Commerce; 1887-96 (Paris, 1898), 2, 108; Statistisches Jahrbuch für das Deutsche Reich vol. 13 (Berlin, 1892), 82-83; Statistical Abstracts for the United Kingdom in each of the Last Fifteen Years from 1886 to 1900 (London, 1901), 92-93. 
over produced enough cotton to feed approximately 105 million factory spindles, compared to about 48 million before the American Civil War.

As the case of the American South confirms, enmeshing cultivators in a quagmire of debts, often combined with extra-economic coercion and a lopsided distribution of political power, proved to be an efficient way to encourage tenant farmers, peasants, and sharecroppers throughout the world to produce everincreasing amounts of raw cotton. ${ }^{61}$ The destruction of slavery and the failure of merchants, manufacturers, and statesmen to impose wage labor on cotton growers or to buy cotton from precapitalist producers had resulted in the emergence of a new system of labor. ${ }^{62}$ This was the second new pillar of the postwar empire of cotton. While cultivators were now nominally free, networks of credit in every cotton-growing region of the world captured them in an ongoing cycle of indebtedness that required them to grow cash crops. The new growers of cotton owned themselves, but their freedom continued to be severely limited by contractual relations between borrowers and lenders, tenants and landlords.

THESE WERE MONUMENTAL CHANGES to the worldwide web of cotton production. New forms of labor control in ever-larger areas of the world had replaced the efforts of slaves in the southern United States. But this new combination of land, labor, and capital could not be affected by manufactures, merchants, and landowners alone. They had to draw on the support from their respective governments. In fact, the new empire of cotton demanded new forms of state intervention, both in order to expand its scope as well as to secure its new ways of extracting labor.

Of course, state power had been essential to the antebellum web of cotton production as well; after all, it was the American government that had emptied cotton territories of their native inhabitants and enforced the institution of slavery. Yet just as the 1860 s saw a significant decline of bonded labor, emancipation accelerated the tendency of states to structure more actively the empire of cotton. While the antebellum empire of cotton had been a world in which planters, factory owners, and aristocrats coerced their dependents to labor, the new world was one in which states used their coercive powers to secure land, labor, and markets for cotton. What seems at first contradictory developments-emancipation and a new imperialism-were instead two grand movements within the same vast system: the destruction of slavery, along with the emergence of the United States as a power in manufactured cotton in its own right, motivated nearly all European states to secure labor, cotton lands, and markets in territories they controlled. ${ }^{63}$ Local sovereignties

${ }^{61}$ For a discussion on the U.S. South, see J. William Harris, "The Question of Peonage in the History of the New South," in Plain Folk of the South Revisited, Samuel C. Hyde, Jr., ed., (Baton Rouge, La., 1997), 100-25.

${ }^{62}$ This was also the case in many other countries. In Peru, for example, tenant farming and sharecropping became the dominant form of cotton production in the wake of the Civil War and the enormous expansion of output that resulted from it. See Vincent C. Peloso, Peasants on Plantations: Subaltern Strategies of Labor and Resistance in the Pisco Valley, Peru (Durham, N.C., 1999).

${ }^{63}$ For an argument about the increasing importance of economic space controlled by powerful imperialist nations, see also Giovanni Arrighi, The Long Twentieth Century: Money, Power, and the Origins of Our Times (London, 1994), 262. 
and domains gave way to empires. This was the third new pillar of the empire of cotton.

The most significant shift within this rise of a new imperialism was the unprecedented commitment of states to secure raw materials and markets for their domestic cotton industries. Consolidating imperial rule, commitments to infrastructure construction, and securing property rights in places distant from the metropolis all were part of this process. The American Civil War had convinced statesmen and cotton manufacturers everywhere that depending on a single supplier of cotton, especially one that seemed as politically unstable as the United States, was dangerous to the economic well-being of their factories and their rival nation-states. Although the last third of the nineteenth century saw the rise of new industries that were much more dynamic and capital intensive than textile mills, the cotton industry remained the largest single employer of labor, the heaviest consumer of imported commodities, and the most significant exporter. As "Foresight" asked in a letter to the editors of the Liverpool Mercury in the summer of 1862 after considering the hard times in a cottonless Lancashire: "Is it not far wiser and more prudent to be endeavoring to raise a permanent supply in countries our own?"64

Manufacturers, consequently, appealed to their respective national governments to open new and more reliable sources of cotton. During the war itself, the Manchester Cotton Supply Association had been the single most insistent voice favoring government intervention to promote colonial cotton growing, but in the decades after the war, similar associations emerged throughout the world of cotton, such as the Empire Cotton Growing Association, the British Cotton Growing Association, the (Russian) Central Asia Trading Association, the (French) Association Cotonnière Coloniale, and the (German) Kolonial-Wirtschaftliches Komitee. They all now pressured various governments to grow cotton on colonial soil, a move, they hoped, that would also increase markets for cotton goods, as colonial subjects would exchange their cotton for manufactured textiles. ${ }^{65}$ While it is possible and even likely that such pressures would have built without the U.S. Civil War (given the new opportunities suggested by colonial possessions), manufacturers evoked over and over again the memory of the cotton famine, giving a new sense of urgency to their demands. ${ }^{66}$

64 LM, August 12, $1862,7$.

65 Trying to "obviate the evils arising from our present position of dependence upon one main source of supply." Resolution passed by the Manchester Cotton Supply Association, reprinted in The Merchants' Magazine and Commercial Review, June 1861, 678; Arthur Redford, Manchester Merchants and Foreign Trade, 1794-1858 (Manchester, 1934), 217, 227; Kolonial-Wirtschaftliches Komitee, Baumwoll-Expedition nach Togo, Bericht (Berlin, 1901). See also Isaacman and Roberts, Cotton, Colonialism, and Social History; Records of the Togo Baumwollgesellschaft mbh, Record Group 7,2016, Staatsarchiv Bremen, Bremen, Germany; Satya, Cotton and Famine in Berar, 55; Thaddeus Sunseri, Vilimani: Labor Migration and Rural Change in Early Colonial Tanzania (Portsmouth, 2002); Sven Beckert, "From Tuskegee to Togo: The Problem of Freedom in the Empire of Cotton," unpublished paper, 2004; Earle, "Egyptian Cotton and the American Civil War," 520; Zeitfragen: Wochenschrift fuer deutsches Leben (May 1, 1911), 1; Kolonial-Wirtschaftliches Komitee, Baumwoll-Unternehmungen 1902, 1903 (Berlin, 1903), 5; Thaddeus Sunseri, "The Baumwollfrage: Cotton Colonialism in German East Africa," Central European History 34 (2001): 33. The link between expanded cotton production of exports and larger import markets was frequently made by advocates of colonial cotton growing. See, for example, Karl Supf, "Deutsch-koloniale Baumwoll-Unternehmungen, Bericht VIII," Der Tropenpflanzer 11 (April 1907), 219.

66 See, for example, Zeitfragen (May 1, 1911), 1 
This story can be told from many different perspectives. In imperial Russia, to take a prominent example, for nearly half a century before the American Civil War, farsighted government bureaucrats, along with a group of merchants and manufacturers, had envisioned Transcaucasia and Central Asia as a source of raw cotton for the domestic industry, with the Russian commander-in-chief in the Caucasus, Baron G.V. Rosen, hoping that "there would be our Negroes." 67 Yet as late as 1857 , not much had come out of these efforts, and Central Asian cotton supplied only 6.5 percent of the needs of the Russian industry. ${ }^{68}$ It was only during the American Civil War that efforts to grow cotton on native soil succeeded, when a group of cotton mill owners, united in the Central Asian Trading Association, met in Moscow to find ways to expand cotton production in Central Asia. ${ }^{69}$ Encouraged by a tripling of prices, cotton exports from Central Asia to Russia increased 4.6 times to 24 million pounds between 1861 and $1864 .{ }^{70}$ Manufacturers now pressured the Russian government to acquire Central Asian territories; a pressure that was not disagreeable to a government whose paramount interest was countering British designs on that region. ${ }^{71}$

While American cotton regained some of its Russian markets after 1865, Central Asian cotton was launched on a path of permanent expansion. As the journal of Moscow capitalists Moskva reported in an 1867 article on "The Influence of the American War on the Cotton Business in Russia," the war helped Russia "rear and foster its native raw material." 72 After the consolidation of Russian rule over Central Asia in the $1860 \mathrm{~s}$ and $1870 \mathrm{~s}$, large-scale infrastructure projects, especially the building of railroads, were undertaken with the strong support of the imperial government. In remote areas it had taken up to six months to transport cotton by camel to the nearest railroad station; with the expansion of railroads,

${ }^{67}$ Quoted in M. K. Rozhkova, Ekonomicheskaia politika tsarskogo pravitel'stva na Srednem Vostoke vo vtoroi chetverti XIX veka i russkaia burzhuaziia (Moscow, 1949), 100. On earlier hopes for Central Asia as the cotton supplier to Russia, see also Pavel Nebol'sin, Ocherki torgovli Rossii s Srednei Aziei (St. Petersburg, 1855), 18, 22, 25, 27. Textile manufacturer Aleksandr Shipov stressed as early as 1857 the importance of securing access to Central Asian cotton. See Aleksandr Shipov, Khlopchato-bumazhnaia promyshlennost' $i$ vazhnost' eia znacheniia v Rossii, vol. 1 (Moscow, 1857), 49-50. See also Charles William Maynes, "America Discovers Central Asia," Foreign Affairs 82 (March/April 2003), 120.

68 Rozhkova, Ekonomicheskie sviazi Rossii so Srednei Aziei, 54-55, tables 9-10.

${ }^{69}$ Quote in Ekonomicheskie sviazi Rossii so Srednei Aziei, 64-65. That the Civil War cotton shortage resulted in a greater attention among Russian cotton capitalists to the need to grow cotton in Central Asia, is also argued by Rozhkova, Ekonomicheskie sviazi Rossii so Srednei Aziei, 150-52.

${ }^{70} \mathrm{~A}$ pood (or $35.24 \mathrm{Ibs}$ ) of Asian cotton sold for 7.75 rubles in 1861 , but by 1863 the price had increased to more than 22 rubles. P. A. Khromov, Ekonomicheskoe razvitie Rossii v XIX-XX Vekah: 1800-1917 (Moscow, 1950), 183. In some regions, such as in the Erivan province (in the Caucasus), cotton production during the Civil War increased nearly tenfold, from 30,000 poods in 1861 to 273,000 poods in 1870. K. A. Pazhitnov, Ocherki istorii tesktil' noi promyshlennosti dorrevoliutsionnoi Rossii: Khlopchato-Bumazhnaia l'no-pen' kovaia i shelkovaia promyshlennost (Moscow, 1958), 98; Rozhkova, Ekonomicheskie sviazi Rossii so Srednei Aziei, 55-61.

71 On January 8, 1866, Tsar Alexander II received a memorandum written by the minister of finance in favor of the exertion of greater influence on Central Asia, which listed among the supporters of such a project the names of a group of Russian capitalists, including owners of such prominent cotton ventures as Ivan Khludov \& Sons, Savva Morozov \& Sons, V. I. Tertyakov, and D. I. Romanovskii. See N. A. Khalfin, Prisoedinenie Srednei Azii k Rossii: 60-90 gody XIXv (Moscow, 1965), 211. On the general debate about Russian imperialism, see Andreas Kappeler, The Russian Empire: A Multiethnic History, Alfred Clayton, trans., (Harlow, 2001), 193; Dietrich Geyer, Der russische Imperialismus: Studien über den Zusammenhang von innerer und auswärtiger Politik, 1860-1914 (Göttingen, 1977).

${ }^{72}$ Moskva, February 1, 1867, n. 
transportation time was cut to two days. The government also created seed plantations, distributed improved seeds to local growers, and sent agronomists to help farmers improve agricultural techniques. At the same time, large cotton manufacturers from Lodz and Moscow erected cotton gins in Turkestan and sent out agents who advanced credit to local growers on the security of their future crop. ${ }^{73}$ As a result, as early as the 1880 s, a quarter of all cotton used in Russian cotton factories was grown in Turkestan and more than half by 1909, enough for one historian to call the province "the cotton colony of Russian capitalism." 74 Russia had turned into one of the most important cotton growing countries in the world, ranking fifth behind the United States, India, China, and Egypt. ${ }^{75}$

Less spectacular but nonetheless important stories could be told about France, Germany, Britain, and Portugal as well. ${ }^{76}$ In each, a major shift took place, as the world cotton industry came to be structured more by imperial states and their colonies, and less by the workings of the market organized by capitalists themselves. States intervened further by raising tariffs on cotton goods. As a result, export markets in colonies, both actual and informal, became dramatically more important: in 1820, Great Britain had exported 73 percent of its cotton textiles to Western Europe and the United States, but by 1896 , only 24 percent went to those areas, while 76 percent were shipped to areas under formal or informal British control. Even for such a latecomer to capitalism and imperialism as Japan, the small but captive Korean market eventually became one of the most important outlets for Japanese textiles. ${ }^{77}$

Throughout Europe, the move toward state intervention was largely initiated by cotton manufacturers, not cotton merchants, a fact that led the Manchester Cotton Supply Association to complain, that "it has been extremely difficult to obtain in Liverpool the smallest subscription to this object." Only a little more than 1 percent of their annual expenditures, they bemoaned, had come from that city. ${ }^{78}$ In Germany as well, it was largely cotton manufacturers from Saxony and elsewhere who pressured the imperial government to support cotton growing in German East

\footnotetext{
${ }^{73}$ John Whitman, "Turkestan Cotton in Imperial Russia," American Slavic and East European Review 15, no. 2 (1956): 190-205.

${ }^{74}$ Whitman, "Turkestan Cotton," 201; Anlage zum Bericht des Kaiserlichen Generalkonsulats in St. Petersburg, December 26, 1913, R 150F, FA 1, 360, BA Berlin. The quotation can be found in P. I. Liashchenko, Istoriia Narodnogo Khoziaistva SSSR, vol. 2 (Moscow, 1956), 542.

75 Karl Supf, "Zur Baumwollfrage," in Kolonial-Wirtschaftliches Komitee, Baumwollexpedition nach Togo [no date, but probably 1900], pp. 4-6, in R 150F, FA 1, 332, BA Berlin; Gately, The Development of the Russian Cotton Textile Industry, 169.

76 The Portuguese government, for example, "on the occasion of the present state of things in America," offered cheap land and other encouragement to planters who might want to produce cotton in its African colonies of Angola and Mozambique as early as December 1861. See LM, January 17, 1862,3 . The French government encouraged cotton growing in Algeria. See LM, April 2, 1862, 3; June 17, 1862, 8. On Germany, see Beckert, "From Togo to Tuskegee."

77 Peter Duus, "Economic Dimensions of Meiji Imperialism: The Case of Korea, 1895-1910," in The Japanese Colonial Empire, 1895-1945; Ramon Hawley Myers and Mark R. Peattie, eds. (Princeton, N.J., 1984), 152.

${ }^{78}$ Letter to the editors, Isaac Watts, Secretary of the Cotton Supply Association, Manchester, November 23,1863 as printed in the $L M$, November $26,1863,7$.
} 
Africa and Togo, while in France, cotton manufacturers from the Alsatian city of Mulhouse agitated for colonial cotton production. ${ }^{79}$

The new importance of imperial states to the worldwide web of cotton production, emerging in the wake of the Civil War, was quite a departure from the merchant-driven world of cotton of the early nineteenth century. Such a reorientation required great ideological effort to justify. The rationale for such a departure was partly strategic: as British Prime Minister Lord Palmerston wrote to Lord Russell in 1861, "it is of the utmost Importance to us to get a regular supply of Cotton from Africa or India, because as long as we are dependent on America alone for our supply we are not politically in a condition to deal with the United States with free and independent action." 80

But this political argument was overshadowed by an understanding that the opening of a new source of labor and the construction of new forms for its extraction demanded decisive state involvement. For that reason, even The Economist, the world's leading exponent of free trade and laissez-faire capitalism, came to favor state involvement in securing cotton, especially from India. It was hard to justify these steps in terms of the laws of supply and demand, but eventually The Economist found a way. India was a place where economic laws simply did not function. "There appears to exist in many important parts of Indian society," The Economist noted, "very peculiar difficulties, which to some extent impede and counteract the action of the primary motives upon which political economy depends for its efficacy." In India, they continued, "the primitive prerequisites of common political economy... are not satisfied. You have a good-demanding Englishman, but, in plain English, not a good-supplying Indian." For that reason, "[t]here is no relaxation of the rules of political economy in the interference of Government in a state of facts like this. Government does not interfere to prevent the effect and operation of "supply and demand," but to create that operation to ensure that effect... There is no greater anomaly in recommending an unusual policy for a State destitute of the ordinary economical capacities, than in recommending an unusual method of education for a child both blind and deaf." 81 India, The Economist was saying, was "blind and deaf" to "economic laws" and therefore in need of state initiative and coercion. ${ }^{82}$ As the President of the Manchester Chamber of Commerce Henry Ashworth put it in 1863, "we cannot afford to wait until price has done it." 83

Not only did states now play a decisive role in securing cotton labor in new territories, they also played a decisive role in securing new ways of extracting labor by laying unprecedented claim upon their subjects by enforcing the rules of the market. From Georgia to Berar, from Egypt to Brazil, governments and courts persistently undermined older collective claims to resources such as grazing and

79 Sunseri, Vilimani, 1-25; Bulletin de la Société Industrielle de Mulhouse 32 (Mulhouse, 1862): 347; Antoine Herzog, L'Algerie et la Crise Cotonnière (Colmar, 1864).

${ }^{80}$ Lord Palmerston to John Russell, Broadslands, October 6, 1861, Box 21, 30/22, Lord John Russell Papers, PRO. Similar arguments were also made by German colonial advocates.

${ }^{81}$ Econ, October 4, 1862, 1093-94.

${ }^{82}$ Manchester Chamber of Commerce, Forty-Third Annual Report, 37; Hansard Parliamentary Debates, 3d ser., vol. 172 (1863), 1999-2001; Harnetty, "The Imperialism Of Free Trade," 333-49; Manchester Chamber of Commerce, The Forty-Second Annual Report, 11.

${ }^{83}$ Manchester Chamber of Commerce, Forty-Second Annual Report, 22. 
hunting rights, forcing cultivators to dedicate themselves single-mindedly to the production of cotton. Colonial states created new kinds of property rights in land and they regulated cotton production and local cotton markets often in excruciating detail. Moreover, court-enforced lien laws allowed creditors to undermine cultivators' claim to the land, and enmesh them in a quagmire of debts, which forced them to grow ever more cotton. The systems of mutual dependence and personal domination that had characterized the countryside of Berar, Egypt, the American South, and elsewhere before the Civil War gave way to a world in which creditors backed by the state coerced cultivators to cultivate agricultural commodities for world markets. The imperialism of free trade that had allowed merchants great leeway in structuring the empire of cotton increasingly gave way to the enclosure of capital and capitalists in nation-states. These nation-states had a much greater claim on their citizens and subjects than ever before. States and capitalists in effect fused their respective goals of power and accumulation in novel ways, in turn leading to a new form of capitalist globalization. ${ }^{84}$

As A RESULT OF THE unprecedented commitment of states to secure the flow of cotton on behest of cotton industrialists, strikingly similar systems of labor spread around the globe. For rural cultivators themselves, this new integration into capitalist world markets presented enormous new opportunities, but also enormous new risks.

During the war, their gamble paid off, as the price of fair Surat cotton in Liverpool quadrupled from 1860 to 1864 , benefiting not only the ubiquitous middlemen but also the cultivators themselves. Stories about Indian cotton growers putting silver wheels on their carts were no doubt exaggerated, but many contemporaries reported rising living standards among Indian, Egyptian, and Brazilian cultivators. Once world market prices declined in the wake of the Civil War (although at first remaining well above their antebellum level), however, and especially after the onset of the global depression of 1873, rural producers had a hard time making up for lost income, especially because falling prices made it ever more difficult to repay loans and make tax payments. Although historians disagree as to how much the fall in world market prices affected cultivators, at the very least, world market integration increased the economic uncertainty faced by people in remote corners of the world. Their incomes, and quite literally their survival, were newly linked to global price fluctuations over which they had little control. Moreover, as world market integration usually went along with social differentiation, a growing group of landless tenants and agricultural laborers, especially in India and Brazil, periodically faced life-threatening difficulties accessing food crops. ${ }^{85}$

${ }^{84}$ Charles S. Maier, "Consigning the Twentieth Century to History: Alternative Narratives for the Modern Era," in AHR 105, no. 3 (June 2000), 807-831; Eric Hobsbawm, The Age of Empire, 1875-1914 (New York, 1987), 69; Michael Mann, The Sources of Social Power: The Rise of Classes and Nation-States, 1760-1914 (New York, 1993); Arrighi, The Long Twentieth Century 11.

85 Todd, World's Cotton Crops, 429-32; Rivett-Carnac, "Report on the Cotton Department for the Year 1868-1869," 132; Satya, Cotton and Famine in Berar, 80. For Egypt see Owen, Cotton and the Egyptian Economy, 107, 159. For Brazil, see Barbosa, "Cotton in Nineteenth Century Brazil," 31, 95-102, 105-08, 142. For western Anatolia (which also witnessed a dramatic increase of cotton 
This threat became most pronounced once world market prices for cotton plunged during the Depression of 1873. The price for Surat cotton, delivered in Liverpool, fell by 38 percent between 1873 and $1876 .{ }^{86}$ Cultivators in Brazil, Egypt, and India, often highly indebted to local moneylenders, now faced plummeting returns on their cash crops. In India and Brazil, the problems were compounded by severe droughts that led to a rapid increase in food prices. Between 1864 and 1873 , the amount of cotton that a peasant had to produce to buy a given quantity of Berar's most important food grain-jowar-doubled and it doubled once more by 1878. Perhaps even more significant, the relative price of food grains to cotton changed dramatically from year to year (changes of 20 percent or even 40 percent were not exceptional), introducing a new degree of uncertainty into rural producers' precarious lives. ${ }^{87}$

Such uncertainty could at times become life threatening. By 1877 and again in the late 1890s, Berar as well as northeastern Brazil, witnessed the starvation of tens of thousands of cultivators, as cotton prices fell while food grain prices rose, putting food out of reach of many cotton producers. During the 1899-1900 famine, about 8.5 percent of the population of Berar died, with the greatest numbers of deaths occurring in districts most specialized in cotton production. In the town of Risod, a contemporary observed, people "died like flies." In Brazil, 500,000 people allegedly starved or died of disease. ${ }^{88}$ Landless agricultural workers suffered in particular, "for not only did they have to pay more for their food, but their wages were reduced from the competition" with workers from other regions. Famine was not caused by a lack of food (indeed, food grains continued to be exported from Berar), but by the inability of the poorest cotton growers to buy it. ${ }^{89}$

Experiencing new uncertainty due to world market integration and pressured by

production for world markets during the Civil War), see Orhan Kurmu "The Cotton Famine and its Effects on the Ottoman Empire," in The Ottoman Empire and the World-Economy, Hurá İslamoğluİnan, ed. (Cambridge, 1987), 169.

86 Todd, The World's Cotton Crops, 429-432. (In nominal terms.)

${ }^{87}$ Data taken from “Index Numbers of Indian Prices 1861-1926," No. 2121, Calcutta: Government of India Central Publication Branch, 1928, Summary Tables III and VI, IOL. On the new uncertainty introduced by world market integration see also Nelson, Central Provinces District Gazetteers, Amraoti District, 226. See also Rivett-Carnac, "Report on the Cotton Department for the Year 1867-68," 52. Interestingly, already in 1790 the East India Company had anticipated the possibility of famine as a result of a greater concentration among peasants on cotton growing. See "Objections to the Annexed Plan," November 10, 1790, 483-89, in Home Department, Missc., 434, IOL. A similar warning was issued in 1874. "Memo by the Department of Agriculture, Revenue and Commerce, Fibres and Silk Branch to the Home Department, Calcutta, June 24, 1874," in Revenue, Agriculture and Commerce Department, Fibres and Silk Branch, June 1874: 41/42, Part B, NAI.

88 Anthony L. Hall, Drought and Irrigation in North-East Brazil (Cambridge, 1978), 4. He explicitly links the shift to cotton to the devastating impact of the drought.

89 Barbosa, "Cotton in Nineteenth Century Brazil," 105. He shows that Pernambuco was not self-sufficient in food, which created tremendous pressures on cotton farmers when the price for cotton fell and that of food grains rose. "The scarcity of 1896-97 was caused by high prices and not by failure of crops," reported the Deputy Commissioner of the Akola District (in Berar) to the Indian Famine Commission. See Indian Famine Commission (Calcutta, 1901), “Appendix, Evidence of Witnesses, Berar," 43, 53. For the mortality figures see Indian Famine Commission, "Appendix, Evidence of Witnesses, Berar," 54. Total mortality between December 1899 and November 1900 was 84.7 per 1000 . For the quotation see Indian Famine Commission, "Appendix, Evidence of Witnesses, Berar," 213. On competition among workers, see Nelson, Central Provinces District Gazetteers, Amraoti District, 276. On famines in the late nineteenth century, see also Mike Davis, Late Victorian Holocausts: El Niño Famines and the Making of the Third World (London, 2001). 
moneylenders, cotton growers in Brazil, India, Egypt, and also the southern United States rebelled. In Brazil, during the Quebra Quilos revolt of 1873-1874, cultivators, many of whom had only recently switched to cotton production, destroyed land records and refused to pay taxes that they could no longer afford as their incomes dropped precipitously in the wake of the global fall of cotton prices. In India, the Deccan Riots of May and June 1875 targeted moneylenders and merchants-figures who symbolized world market penetration. In Egypt, peasants joined the 'Urabi revolt of 1882, drawn to the promise to "banish the usurer." More than a decade later, cotton farmers in the southern United States built a political movement, populism, and demanded that the government relieve them of some of the economic pressures that had wrecked havoc with their lives. Throughout the world, however, cotton growers had been politically marginalized, limiting the impact of these rebellions. ${ }^{90}$

Indeed, despite this resistance, cotton manufacturers, merchants, and government bureaucrats succeeded to a striking extent in reconstructing the empire of cotton in the wake of the American Civil War, even if not always on their own terms. This reconstruction was not the outcome of the gradual emergence of integrated world markets in agricultural products, but a sudden, violent transformation of the production of one of the industrial world's central commodities. To be sure, changes would have come to the world of cotton even without the war, but it was the war that focused the attention of states and capitalists, allowing them to take radical steps.

The worldwide web of cotton production itself, however, was far from static, as it continued to evolve rapidly and unpredictably in the decades after the American Civil War. These changes, in turn, reinforced the departures initiated by the war itself. Perhaps most prominently, the position of the United States within the empire of cotton shifted as it became itself a major manufacturer of cotton yarn and cloth, in effect using an ever-higher percentage of its own cotton in its own factories-from around 20 percent before the Civil War to 35 percent after 1865 . As a result, by 1890,17 percent of all spindles in the world were now located in the United States, compared to only 11 percent in 1860 . In 1900, the United States was indeed the world's second most important cotton manufacturing power after the United Kingdom, counting 2.4 times more spindles in its factories than its nearest competitor, Germany. This new role of the United States in itself was an outcome of the war, which had destroyed the political power of Southern slaveholders and their vision of subordinated economic development, in effect subduing the world's last powerful group of cotton growers. The political economy of continental industrialization now won out over the political economy of Atlantic trade. ${ }^{91}$

90 On Brazil, see Roderick J. Barman, "The Brazilian Peasantry Reexamined: The Implications of the Quebra-Quilo Revolt, 1874-1875," Hispanic American Historical Review 57, no. 3 (1977): 401-24; Armando Souto Maior, Quebra-Quilos: Lutas Sociais No Outono do Império (Sao Paulo, 1978). The pressure of raising taxes was also felt by Egyptian cultivators who lost in the process most of the profits that they had accumulated during the Civil War. See Owen, Cotton and the Egyptian Economy, 144. On the Indian riots see Neil Charlesworth, "The Myth of the Deccan Riots of 1875," Modern Asian Studies 6, no. 4 (1972): 401-21; "Papers Relating to the Indebtedness of the Agricultural Classes in Bombay and Other Parts of India" (Bombay, 1876), "Report of the Committee on the Riots in Poona and Ahednagar, 1875." Further (grain) riots took place during the famine of 1899-1900. See Department of Revenue and Agriculture, Famine Branch, November 1899, nos. 14-54, Part B, NAI; Ravinder Kumar, Western India in the Nineteenth Century: A Study in the Social History of Maharashtra (London, 1968), 186. On Egypt, see Richards, Egypt's Agricultural Development, 42.

${ }^{91}$ Hammond, The Cotton Industry, appendix; Beckert, Monied Metropolis. 
Not only did the position of the United States shift, but also cotton industrialization proceeded at breakneck speed in continental Europe, especially in Germany and Russia, and eventually in Asia, especially in Japan and India. Rapid industrialization resulted in mounting global demand for cotton, and, perhaps most importantly, in increasing concerns among various states to secure access to that cotton, feeding the frantic global effort to dominate the world's cotton growing areas politically. These developments, in turn, reinforced the search for new sources of labor and new forms of labor control. ${ }^{92}$ (See Figure 5.)

${ }^{92}$ This graph is based on the author's analysis of data on cotton spindles from nineteen countries (Austria, Belgium, Brazil, Canada, China, France, Germany, India, Italy, Japan, Mexico, Netherlands, Portugal, Russia, Spain, Sweden, Switzerland, United Kingdom, and the United States). Due to the dispersed and inconsistent nature of the sources, this is not more than an estimate. Some numbers have been extrapolated. For the numbers, see Louis Bader, World Developments in the Cotton Industry, with Special Reference to the Cotton Piece Goods Industry in the United States (New York, 1925), 33; Amiya Kumar Bagchi, Private Investment in India, 1900-1939, Cambridge South Asian Studies 10 (Cambridge, 1972), 234; Javier Barajas Manzano, Aspectos de la industria textil de algodón en México (Mexico, 1959), 43-44, 280; Belgium, Ministère de L'Intérieur; Statistique de la Belgique, Industrie (Bruxelles, 1851), 471; Pierre Benaerts, Les Origines de la Grande Industrie Allemande (Paris, 1933), 486; Sabbato Louis Besso, The Cotton Industry in Switzerland, Vorarlberg, and Italy; A Report to the Electors of the Gartside Scholarships (Manchester, 1910); George Bigwood, Cotton (New York, 1919), 61; The Cambridge Economic History of Europe, 8 vols., H. J. Habakkuk and M. Postan, eds. (Cambridge, 1965), 6: 443; Kang Chao, The Development of Cotton Textile Production in China (Cambridge, Mass., 1977), 301-07; Stanley D. Chapman, "Fixed Capital Formation in the British Cotton Industry, 1770-1815," The Economic History Review, n.s., 23, no. 2 (August 1970): 235-266, 252; Louis Bergeron and JeanAntoine-Claude Chaptal, De l'industrie française: Acteurs de l'histoire(Paris, 1993), 326; Melvin Thomas Copeland, The Cotton Manufacturing Industry of the United States (New York, 1966), 19; Cotton Facts: A Compilation from Official and Reliable Sources (New York, 1878), see years 1878-1920; Richard Martin Rudolph Dehn, The German Cotton Industry: A Report to the Electors of the Gartside Scholarships (Manchester, 1913); Thomas Ellison, A Hand-book of the Cotton Trade, or, A Glance at the Past History, Present Condition, and the Future Prospects of the Cotton Commerce of the World (London, 1858), 146-67; Thomas Ellison, The Cotton Trade of Great Britain (1886; New York, 1968), 72-73; D. A. Farnie, The English Cotton Industry, 180; Mimerel Fils, "Filature du Cotton," in Exposition Universelle de 1867 à Paris, 8 vols., M. Chevalier, ed. (Paris, 1868), 4: 20; R. B. Forrester, The Cotton Industry in France; a Report to the Electors of the Gartside Scholarships (London, 1921), 5; "Industrie Textile," Annuaire statistique de la France (Paris, 1877-1890, 1894); Michael Gately, "The Development of the Russian Cotton Textile Industry," 134; Statistisches Reichsamt, Statistisches Jahrbuch für das Deutsche Reich (1913), 34: 107; Aurora Gómez Galvarriato, "The Impact of Revolution: Business and Labor in the Mexican Textile Industry, Orizaba, Veracruz, 1900-1930," (PhD dissertation, Harvard University, 2000), 23, 45; Great Britain, Committee on Industry and Trade, Survey of Textile Industries: Cotton, Wool, Artificial Silk (London, 1928), 142; International Federation of Master Cotton Spinners' and Manufacturers' Associations, International Cotton Statistics, Arno S. Pearse, ed. (Manchester, 1921), 1-32; International Federation of Master Cotton Spinners' and Manufacturers' Associations and Arno S. Pearse, The Cotton Industry of India, being the Report of the Journey to India (Manchester, 1930), 22; International Federation of Master Cotton Spinners' and Manufacturers' Associations and Arno S. Pearse, The Cotton Industry of Japan and China, Being the Report of the Journey to Japan and China (Manchester, 1929), 18-19, 154; Italy, Ministero Di Agricoltura, Industria e Commercio, "L'industria del Cotone in Italia," Annali di Statistica, series 4 (Rome, 1902), 100: 12-13; Italy, Ministero Di Agricoltura, Industria, e Commercio, Annuario Statistico Italiano (Rome, 1878-), see years 1878, 1881, 1886, 1892, 1900, 1904, and 1905-1906; S. T. King and Ta-chün Liu, China's Cotton Industry: A Statistical Study of Ownership of Capital, Output, and Labor Conditions (1929), 4; Sung Jae Koh, Stages of Industrial Development in Asia: A Comparative History of the Cotton Industry in Japan, India, China, and Korea (Philadelphia, Pa., 1966), 324-66; Richard A. Kraus, Cotton and Cotton Goods in China, 1918-1936 (New York, 1980), 57, 99; John C. Latham, and H. E. Alexander, Cotton Movement and Fluctuations (New York, N.Y, 1894-1910); Maurice Lévy-Leboyer, Les banques européennes et l'industrialisation internationale dans la première motié du XIX ${ }^{e}$ siècle (Paris, 1964), 29; S. D. Mehta, The Indian Cotton Textile Industry, an Economic Analysis (Bombay, 1953), 139; B. R. Mitchell, Abstract of British Historical Statistics (Cambridge, 1971), 185; B. R. Mitchell, International Historical Statistics: Europe, 1750-1993 4th edn. (London, 1998), 511; Charles Kroth Moser, The Cotton Textile Industry of Far Eastern Countries (Boston, Mass., 1930), 50; National Association of Cotton Manufacturers, 


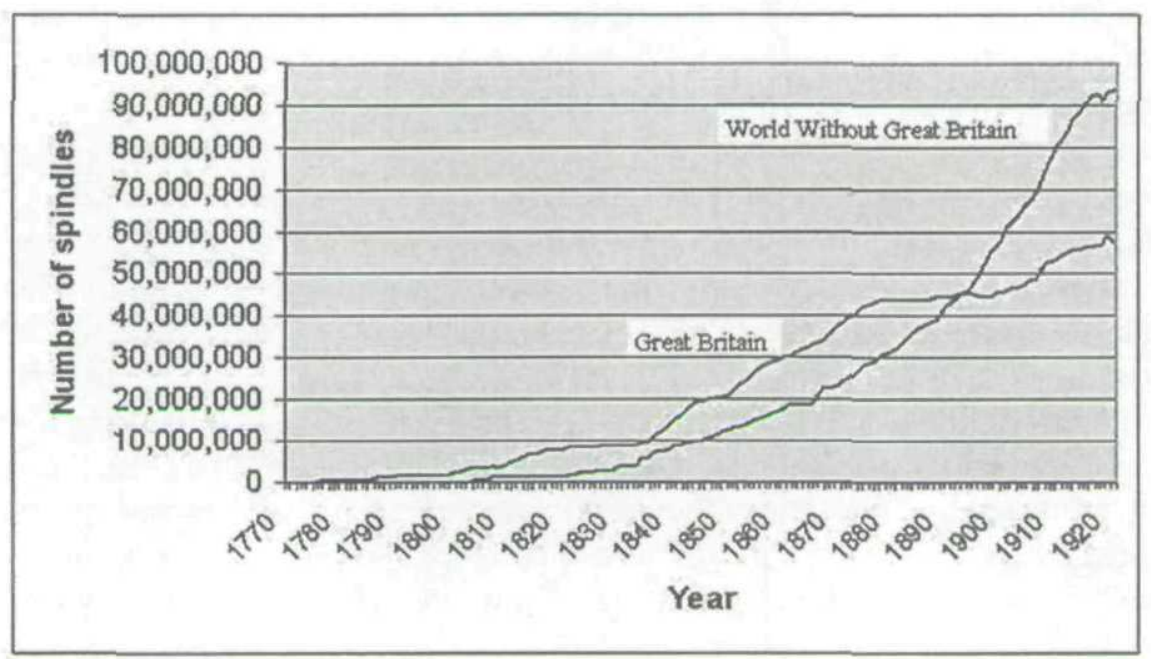

TABLE 3: Number of Factory Spindles, Great Britain and World Without Great Britain, 1770-1920.

“ThE REBEllion," OPINED THE New York World in 1865, "forms the boundary between the first great epoch and a new era in [cotton's] history." 93 Indeed, the disruptions caused by the Civil War years recast the empire of cotton. Its old and seemingly solid pillars-slavery, a powerful planter class in the American South, an industry structured on the relationship between Lancashire and the United States, and networks of trade dominated by merchants operating in relatively open markets-had been undermined and eventually destroyed by the American conflict. Cotton manufacturers and merchants along with government bureaucrats searched for new and viable combinations of land, labor, and state power to bring abundant quantities of inexpensive raw cotton to European factories. The new pillars of a transformed global political economy of cotton, which they hastily constructed during the war, solidified in the decades thereafter, with freedom, cultivators enmeshed in a quagmire of debts, diversification of raw cotton suppliers, and active state intervention to consolidate cotton supplies from colonial dependencies most

Standard Cotton Mill Practice and Equipment, with Classified Buyer's Index (Boston, Mass., 1919), 37; Keijiro Otsuka, Gustav Ranis, and Gary R. Saxonhouse, Comparative Technology Choice in Development: The Indian and Japanese Cotton Textile Industries (New York, 1988), 6; Alexander Redgrave, "Report of Factory Inspectors," in Parliamentary Papers, Great Britain, Parliament, House of Commons (London, 1855), 69; Johann H. Schnitzler, De la Création de la Richesse, ou, Des Intérêts Matériels en France (Paris, 1842), 228; Stanley J. Stein, The Brazilian Cotton Manufacture, 191; Guy Thomson, "Continuity and Change in Mexican Manufacturing," in Between Development and Underdevelopment: The Precocious Attempts at Industrialization of the Periphery, 1800-1870, Jean Batou, ed. (Geneva, 1991), 280; John A. Todd, The World's Cotton Crops (London, 1915), 411; Ugo Tombesi, L'Industria Cotoniera Italiana alla fine del Secolo XIX (Studio Economico-Sociale) (Pesaro, 1901), 66; United States, Bureau of Manufactures, Cotton Fabrics in Middle Europe: Germany, Austria-Hungary, and Switzerland (Washington, D.C., 1908), 23, 125, 162; United States, Bureau of Manufactures, Cotton Goods in Canada (Washington, 1913), 33; United States, Bureau of Manufactures, Cotton Goods in Italy (Washington, D.C., 1912), 6; United States, Bureau of Manufactures, Cotton Goods in Russia (Washington, D.C., 1912), 9-11; United States, Bureau of the Census, Cotton Production and Distribution: Season of 1916-1917 (Washington, D.C., 1918), 88; United States, Bureau of the Census, Cotton Production in the United States, (Washington, D.C., 1915), 56.

${ }^{93}$ New York World, October 9, 1865, 1. 
prominently among them. Manufacturers and state bureaucrats now shaped the empire of cotton, once dominated by planters, and slaves. Ostensibly stable antebellum global networks had been transformed beyond recognition. Capitalism, in Fernand Braudel's words, had once more demonstrated its "unlimited flexibility, its capacity for change and adaptation." 94

The new global political economy of cotton was the outcome of a struggle in which workers and slaves, peasants and sharecroppers, merchants and manufacturers, imperial rulers and government bureaucrats, soldiers and economists, played important roles. Often removed from one another by oceans, deserts, and mountain ranges, incapable of communicating with one another, and inhabiting religious, cultural, and social worlds that were all but mutually incomprehensible, these actors still encountered one another in their common desire to alter their own place within the worldwide web of cotton production. The global empire of cotton, torn asunder by the Civil War, was pulling together far-flung threads to create the warp and woof of a new global political economy.

${ }^{94}$ Fernand Braudel, Civilization and Capitalism, 15th-18th Century, vol. 2 (New York, 1982), 433.

Sven Beckert is professor of history at Harvard University, where he teaches the history of the United States in the nineteenth century. He is the author of The Monied Metropolis: New York City and the Consolidation of the American Bourgeoisie (2001). Currently his work focuses on the history of nineteenthcentury capitalism. He is writing a global history of cotton during the "long" nineteenth century, to be published by Alfred A. Knopf, and a history of the world economy between 1760 and 1880, to be published by Harvard University Press. 
Copyright of American Historical Review is the property of American Historical Association and its content may not be copied or emailed to multiple sites or posted to a listserv without the copyright holder's express written permission. However, users may print, download, or email articles for individual use. 